\title{
Copper sorption by the edge surfaces of synthetic birnessite nanoparticles
}

\section{Jasquelin Peña*1, John Bargar ${ }^{2}$, Garrison Sposito ${ }^{3}$}

\author{
Revised submission to Chemical Geology
}

\author{
${ }^{1}$ Institute of Earth Surface Dynamics \\ University of Lausanne \\ Lausanne, CH 1015
}

Email: jasquelin.pena@unil.ch; Tel: +41216924355

\author{
${ }^{2}$ Stanford Synchrotron Radiation Lightsource Directorate \\ SLAC National Accelerator Laboratory \\ Menlo Park, CA 94025
}

Email: bargar@slac.stanford.edu; Tel: (650) 926-4949
${ }^{3}$ Geochemistry Department, Earth Sciences Division
Lawrence Berkeley National Laboratory
Berkeley, CA 94720

Email: gsposito@berkeley.edu; Tel: (510) 643-8297
*Corresponding author. Tel: +41 21692 4355; Fax: +41 21692 4305;
Email: jasquelin.pena@unil.ch

Keywords: manganese oxide; birnessite; trace metals; copper; sorption; EXAFS spectroscopy 


\section{Abstract}

We investigated the sorption of $\mathrm{Cu}$ by $\delta-\mathrm{MnO}_{2}$, an analog for natural birnessite (layer-type Mn oxide) that is characterized by randomly stacked and curled nanosheets, a low to moderate vacancy content, and variable amounts of layer and interlayer $\mathrm{Mn}^{3+}$. The synthetic $\delta-\mathrm{MnO}_{2}$ used in this study had a Na:Mn molar ratio of 0.13 , an average manganese oxidation number (AMON) of 3.85 after reaction, a specific surface area of $254 \mathrm{~m}^{2} \mathrm{~g}^{-1}$ and particle size of $2-4 \mathrm{~nm}$ in the $a b$ plane. The maximum surface excess $\left(q_{\max }\right)$ value at $\mathrm{pH} 6$ estimated from sorption data of $0.72(0.64-0.83,95 \%$ confidence interval $) \mathrm{mol} \mathrm{Cu} \mathrm{mol}^{-1} \mathrm{Mn}$ far exceeded the nominal vacancy content for $\delta-\mathrm{MnO}_{2}$ (ca. $6-11 \%$ mol vacancy $\mathrm{mol}^{-1} \mathrm{Mn}$ ), thus implicating multiple binding sites for $\mathrm{Cu}$. The large values of $q_{\max }$ and specific surface area of the mineral suggest a major role for surface sites at the particle edges relative to vacancy sites. The extended X-ray absorption fine structure (EXAFS) spectra from $\delta-\mathrm{MnO}_{2}$ samples differ with respect to the EXAFS spectra for $\mathrm{Cu}(\mathrm{OH})_{2}, \mathrm{CuO}$, and $\mathrm{Cu}_{3}\left(\mathrm{CO}_{3}\right)_{2}(\mathrm{OH})_{2}$ and $\mathrm{Cu}-$ sorbed by biogenic $\mathrm{MnO}_{2}$. The $\mathrm{Cu} \mathrm{K}$-edge EXAFS spectra show two second-shell peaks that can be modeled with $\mathrm{Mn}$ and $\mathrm{Cu}$ near-neighbors. Copper appears to bind dominantly at particle edges of $\delta-\mathrm{MnO}_{2}$ as dimers or polynuclear surface species. This sorption mechanism is consistent with the moderate vacancy content of $\delta-\mathrm{MnO}_{2}$ and explains the similarity in the EXAFS spectra from samples having surface loadings of 0.01 to $0.26 \mathrm{~mol} \mathrm{Cu} \mathrm{mol}^{-1} \mathrm{Mn}$. The strong proclivity of $\mathrm{Cu}$ to bind on the edge surfaces of nanoparticulate birnessite leads to very large surface excesses of $\mathrm{Cu}$ without the formation of a discreet precipitate, making the surface sites at the particle edges the dominant sorption site for $\mathrm{Cu}$. 


\section{Introduction}

Copper is a trace metal of environmental concern due to its widespread use in agriculture and the large quantities of $\mathrm{Cu}$ extracted via mining activities (Bradl, 2005). For example, the mass of $\mathrm{Cu}$ extracted annually by mining and fossil fuel production is 632 times greater than the mass released annually through crustal weathering and volcanic activity (Klee and Graedel, 2004; Sposito, 2008). This large anthropogenic mobilization factor-the largest among all metals-reflects the significant anthropogenic perturbation of the global biogeochemical cycle of $\mathrm{Cu}$. In soils and sediments receiving anthropogenic inputs, oxide minerals such as layer-type $\mathrm{MnO}_{2}$ can control the speciation of $\mathrm{Cu}$ through adsorption at the water-mineral interface (Davies-Colley et al., 1984; Jenne, 1968; McLaren and Crawford, 1973).

Birnessite (layer-type $\mathrm{MnO}_{2}$ ) may bind $\mathrm{Cu}$ via three general mechanisms: adsorption at cation vacancy sites, incorporation into the $\mathrm{MnO}_{2}$ sheet and adsorption at lateral edge surfaces. The adsorption of divalent metals at vacancy sites involves the coordination of the metal to the three surface oxygen atoms surrounding the vacancy site, thus forming a triplecorner-sharing (TCS) complex (Manceau et al., 2002; Manceau et al., 2007b). In birnessite suspensions equilibrated with $\mathrm{Cu}$ at low $\mathrm{pH}$ values $(\mathrm{pH} \approx 4.0), \mathrm{Cu}-\mathrm{TCS}$ complexes were inferred from the $\mathrm{Cu}-\mathrm{Mn}$ interatomic distance of 3.39 - $3.43 \AA$ A obtained from fitting extended X-ray absorption fine structure (EXAFS) spectra (Arai, 2011; Manceau et al., 2002; Sherman and Peacock, 2010). The occurrence of up to $20 \% \mathrm{Cu}$-incorporation (Cu-INC) at high $\mathrm{pH}$ values $(\mathrm{pH} \approx 8.0)$ was proposed by Sherman and Peacock (2010) based on the appearance of a peak near $2.9 \AA$ in the Fourier-transformed EXAFS spectrum for $\delta-\mathrm{MnO}_{2}$ sample with a loading of $0.068 \mathrm{~mol} \mathrm{Cu} \mathrm{mol}^{-1} \mathrm{Mn}$. However, in a recent density functional theory (DFT) study, Kwon et al. (2013) demonstrated that the incorporation of $\mathrm{Cu}$ into a vacancy site strongly inhibits the Jahn-Teller distortion of $\mathrm{Cu}$, destabilizing the $\mathrm{Cu}$-INC species relative to 
the $\mathrm{Cu}$-TCS species at any $\mathrm{pH}$ value. The formation of $\mathrm{Cu}$-INC thus appears unfavorable. In addition, the $\mathrm{Cu}-\mathrm{Mn}$ interatomic distance of $2.9 \AA$ may indicate the formation of other surface species. To date there are no reports of $\mathrm{Cu}$ adsorption at birnessite edges, but this mode of adsorption has been reported for $\mathrm{Ni}$ and $\mathrm{Pb}$, which bind at particle edges in either edge- or corner-sharing configurations with respect to Mn octahedra (Manceau et al., 2007b; Takahashi et al., 2007; Villalobos et al., 2005).

Villalobos et al. (2005) have argued that ion adsorption increases as the specific surface area, and thus the fraction of edge surface sites, increases. Their calculations of residual charges based on bond-valence concepts with all charges expressed as monovalent charges showed that a $5 \mathrm{~nm}$ particle with an $8 \%$ vacancy rate would have $70 \%$ of the residual charges located at the particle edges (Villalobos et al., 2005). The formation of Mn oxides in most environments, which occurs predominantly via biological (Learman et al., 2011; Tebo et al., 2004) or surface-catalyzed (Morgan, 2005) oxidation of Mn(II), leads to disordered nanocrystalline birnessite minerals with high specific surface areas (Bargar et al., 2009; Grangeon et al., 2010; Hochella et al., 2005; Manceau et al., 2007a; Manceau et al., 2007b; Marcus et al., 2004; Peacock and Sherman, 2007a; Santelli et al., 2011; Tan et al., 2010; Webb et al., 2005). Consequently, in light of the potentially large fraction of reactive edge sites on birnessite surfaces, we expect particle edges to play an important role in $\mathrm{Cu}$ uptake.

The synthetic birnessite $\delta-\mathrm{MnO}_{2}$ is characterized by curled $\mathrm{MnO}_{2}$ nanosheets with hexagonal sheet symmetry and a small to moderate vacancy content (Grangeon et al., 2008; Manceau et al., 2013; Villalobos et al., 2006). Its high specific surface area and low vacancy content thus make it an optimal choice for studying edge adsorption experimentally. The study of $\mathrm{Cu}$ adsorption at birnessite particle edges is particularly relevant in light of the disagreement between experimental and computational findings regarding the incorporation 
of $\mathrm{Cu}$ into $\mathrm{MnO}_{2}$ (Kwon et al., 2013; Sherman and Peacock, 2010). Moreover, the inability to explain the observed maximum surface excess of $\mathrm{Cu}$ in terms of the nominal vacancy content of the birnessite used (Sherman and Peacock, 2010) implies additional sorption mechanisms. Finally, $\mathrm{Cu}$ speciation on birnessite is not well-documented; only a few samples have been characterized to date, three of which were prepared at $\mathrm{pH} 4$ and one at $\mathrm{pH} 8$ (Arai, 2011; Manceau et al., 2002; Sherman and Peacock, 2010).

In the present study we combine sorption isotherm measurements with EXAFS spectroscopy to identify the mechanism of $\mathrm{Cu}$ sorption by $\delta-\mathrm{MnO}_{2}$ over a broad range of surface loadings and at circumneutral $\mathrm{pH}$. The specific surface area of the $\delta-\mathrm{MnO}_{2}$ used in our experiments is $254 \mathrm{~m}^{2} \mathrm{~g}^{-1}$ (Duckworth and Sposito, 2007), indicating nanoparticulate dimensions and thus an overwhelming fraction of residual charges at the particle edges available to bind $\mathrm{Cu}$. We also expect that vacancy sites contribute to $\mathrm{Cu}$ adsorption in the TCS geometry but that the incorporation of $\mathrm{Cu}$ is unlikely.

\section{Materials and methods}

2.1 Mineral samples. Delta- $\mathrm{MnO}_{2}$ was synthesized according to the "redox" method, which involves mixing a solution of $\mathrm{MnCl}_{2} \cdot 4 \mathrm{H}_{2} \mathrm{O}$ with a solution of $\mathrm{KMnO}_{4}$ in excess $\mathrm{NaOH}$ and with a Mn(VII):Mn(II) molar ratio of 0.67 (Villalobos et al., 2003). The $\delta-\mathrm{MnO}_{2}$ powder used in this study has a specific surface area of $254 \pm 2 \mathrm{~m}^{2} \mathrm{~g}^{-1}$, an average manganese oxidation number $(\mathrm{AMON})$ of $4.02 \pm 0.06$ (prior to reaction), and a Na:Mn content of $26 \pm 0.5 \%$ (Duckworth and Sposito, 2007). A water content of $19 \%$ was determined by thermogravimetric analysis using a $10^{\circ} \mathrm{C} / \mathrm{min}$ heating rate from $25-200^{\circ} \mathrm{C}$ (Metler Toledo TGA 851e). High-resolution TEM (Philips CM300 FEG/UT) images of a $\delta-\mathrm{MnO}_{2}$ specimen show a polycrystalline material with an average particle size of $3.2 \pm 0.6 \mathrm{~nm}$ (10 particles, each measured along $x$ and $y$ directions) in the $a b$ plane (Fig. 1). The average Mn-O and Mn- 
Mn interatomic distances $(R)$ and coordination numbers $(C N)$ in the birnessite samples obtained from shell-by-shell fits of Mn K-edge EXAFS spectra (Table A.1 and Fig. A.1) are consistent with the structural description of $\delta-\mathrm{MnO}_{2}$ given by Villalobos et al. (2006) and Webb et al. (2005).

2.2 Sorption experiments. Copper sorption and $\mathrm{Mn}$ desorption from $\delta-\mathrm{MnO}_{2}$ were measured by equilibrating an oxide slurry with $\mathrm{Cu}$ (II) in a $10 \mathrm{mM} \mathrm{NaCl}$ and $20 \mathrm{mM}$ MES (2-(Nmorpholino)ethanesulfonic acid) solution buffered to $\mathrm{pH}$ 6. Mineral samples were ground to a fine powder in an agate mortar and pestle. Stock suspensions were prepared by adding about $0.35 \mathrm{~g} \mathrm{~L}^{-1}$ solid to the background electrolyte solution. The $\mathrm{MnO}_{2}$ concentration determined from total digestion of the slurry with a mixture of nitric acid and oxalic acid to measure $\mathrm{Mn}_{\mathrm{TOT}}$ and assuming an $\mathrm{M}_{\mathrm{w}}$ for $\mathrm{MnO}_{2}$ of $87 \mathrm{~g} \mathrm{~mol}^{-1}$ was $0.2 \mathrm{~g} \mathrm{~L}^{-1} \mathrm{MnO}_{2}$. To ensure that particles were well dispersed, the suspensions were stirred vigorously for $1.5 \mathrm{~h}$, sonicated for 25 min (Branson 3210 sonicator) and returned to the stir plate for $0.5-1.0 \mathrm{~h}$. To begin a sorption experiment, $15 \mathrm{~mL}$ of the oxide suspension was transferred to a $40 \mathrm{~mL}$ Teflon tube by pipette, followed by the addition of $\mathrm{Cu}$ (II) from a $50 \mathrm{mM} \mathrm{CuCl}_{2}$ solution. Before $\mathrm{Cu}$ addition but after equilibration in the background electrolyte $(10 \mathrm{mM} \mathrm{NaCl}$ and $20 \mathrm{mM} \mathrm{MES}$ buffer), aliquots were removed for determination of the Na:Mn ratio by ICP-OES and AMON by potentiometric titration using Mohr's salt and $\mathrm{Na}$ pyrophosphate. The potentiometric titration method used gives the AMON with a 0.05 uncertainty (Lingane and Karplus, 1946; Vetter and Jaeger, 1966).

Experiments were conducted in duplicate at six concentrations ranging from 0 to 1500 $\mu \mathrm{M} \mathrm{Cu}$. Aqueous speciation calculations including hydrolysis, carbonate and chloride species, and determinations of the relative saturation with respect to various solids $(\Omega=$ $\mathrm{IAP} / \mathrm{K}_{\mathrm{so}}$ ) were made using stability constants from the MINEQL+ thermodynamic database (Schecher and McAvoy, 2001) and initial $\mathrm{Cu}$ concentrations corrected for ionic strength. 
Over the range of concentrations used in sorption experiments, $\mathrm{Cu}^{2+}$ accounts for $96-97 \%$ of the total $\mathrm{Cu}$. All samples were initially undersaturated with respect to the homogeneous precipitation of $\mathrm{Cu}(\mathrm{OH})_{2}(\mathrm{~s})[\Omega=0.08-0.69]$ and $\mathrm{CuCO}_{3}[\Omega=0.003-0.03]$, but not with respect to $\mathrm{Cu}_{2}(\mathrm{OH})_{2} \mathrm{CO}_{3}(\mathrm{~s})[\Omega=1.2-8.0$ for $\mathrm{Cu}>285 \mu \mathrm{M}(\mathrm{pH} 5.9)]$ or $\mathrm{CuO}(\mathrm{s})[\Omega=1.1-$ 8.6 for $\mathrm{Cu}>86 \mu \mathrm{M}(\mathrm{pH} 6.0)]$.

After $50 \mathrm{~h}$ of equilibration on a tabletop shaker (150 RPM), two samples were taken from each tube. A $1 \mathrm{~mL}$ sample of the slurry was digested with nitric acid (50 $\mu \mathrm{L}$ of a $69 \%$ solution) and oxalic acid (50 $\mu \mathrm{L}$ of a $1 \mathrm{~N}$ solution) to determine the total concentrations of $\mathrm{Cu}$ and Mn. A $5 \mathrm{~mL}$ sample of the solution was obtained by filtration through a $0.22 \mu \mathrm{m}$ polyethersulfone syringe filter (Millex ${ }^{\circledR}-\mathrm{GP}$, Millipore) and acidified with nitric acid to determine the aqueous concentrations of $\mathrm{Cu}$ and $\mathrm{Mn}$. A Perkin-Elmer Optima 5300 Inductively-Coupled Plasma Optical Emission Spectrophotometer (ICP-OES) was used to determine $\mathrm{Cu}$ and $\mathrm{Mn}$ concentrations, using $\mathrm{Sc}$ as an internal standard (Table A.2). The pH of the filtered solution $\left(\mathrm{pH}_{\mathrm{eq}}\right)$ was also measured at the time of sampling using a ThermoOrion glass combination $\mathrm{pH}$ electrode and a Beckman $\Phi 71 \mathrm{pH}$ meter (Table A.2).

2.3 Sorption isotherms. Surface excess $(q)$ was expressed as the moles of $\mathrm{Cu}$ accumulated on the sorbent, with the sorbent concentration expressed in terms of the total moles of $\mathrm{Mn}$ in solid phase, as determined by total digestion of the slurry. We chose to express $q$ as a $\mathrm{Cu}: \mathrm{Mn}$ molar ratio, rather than using the standard units of mol $\mathrm{Cu} \mathrm{kg}^{-1}$ sorbent, to facilitate the interpretation of $q$ in terms of sorbent properties such as the vacancy content and number of Mn octahedra at particle edges. Plots of the distribution coefficient $\left(K_{d}=q / c[=] \mathrm{L} \mathrm{mol}^{-1}\right.$, where $\mathrm{c}$ is the concentration of the adsorptive species) against $q$ were examined to determine which sorption model best fit the data (Sposito, 2008).

2.4 X-ray absorption spectroscopy. All XAS studies were conducted at the Stanford Synchrotron Radiation Lightsource (SSRL) at Beam Line 4-1 using a Si (220) double crystal 
monochromator, calibrated to $8979 \mathrm{eV}$ using a $\mathrm{Cu}(0)$ foil. Copper K-edge X-ray absorption spectra were obtained for various samples as outlined in Table 1. A liquid $\mathrm{N}_{2}(\mathrm{~T}=77 \mathrm{~K})$ cryostat was used to prevent beam-induced changes in the samples. At the beam line, samples were filtered onto Millipore Type HA membranes, which were fixed onto the sample holder using Kapton tape. Samples were kept moist in the dark until the time for XAS measurements. Fluorescence-yield (FY) spectra were measured with a Lytle-type gas ionization chamber detector to values of $12 \AA^{-1}$, with samples positioned at a $45^{\circ}$ angle with respect to the incident beam. The peak heights of X-ray absorption near edge structure (XANES) features in fluorescence mode matched those in transmission mode, suggesting that self-absorption of the FY spectra were insignificant. X-ray absorption spectra of $\mathrm{Cu}^{2+}(\mathrm{aq})(50$ $\mathrm{mM} \mathrm{CuCl} 2$ ) and $\mathrm{Cu}(\mathrm{OH})_{2}$ (s) were also measured. The EXAFS spectrum measured for $\mathrm{Cu}(\mathrm{OH})_{2}$ (s) is similar to that published by Cheah et al. (2000). Reference X-ray absorption spectra were obtained from the XAFS Model Compound Data Library for $\mathrm{CuO}(\mathrm{s})$ and $\mathrm{Cu}\left(\mathrm{CO}_{3}\right)_{2} \mathrm{OH}(\mathrm{s})$ (Newville et al., 1999). Finally, a biogenic birnessite sample with $0.02 \mathrm{~mol}$ $\mathrm{Cu} \mathrm{mol}^{-1} \mathrm{Mn}$ adsorbed at vacancy sites $\left[R_{\mathrm{Cu}-\mathrm{Mn}}=3.44 \AA\right.$; $($ Peña, 2009) $]$ is included as a reference.

Both the near edge (XANES) and fine structure (EXAFS) portions of the X-ray absorption spectra were analyzed to determine the $\mathrm{Cu}$ coordination geometry and local bonding environment, respectively. X-ray absorption spectra were averaged and background subtracted using SixPack (Webb, 2004). The XANES spectra $[m u(E)]$ included the signal up to $100 \mathrm{eV}$ above the absorption edge. The $\mathrm{Cu}$ K-edge XANES spectra from the sorption samples were compared with those measured for reference materials. The EXAFS spectra [chi( $k)]$ were $k^{3}$-weighted and converted to $R$-space by fast Fourier transform [FT $\left(\operatorname{chi}(k) * k^{3}\right)$ ] over the $k$ range of $2.5-12 \AA^{-1}$ using a Kaiser-Bessel window with the windowing parameter (dk) set to $3 \AA^{-1}$. 
2.5 Structural modeling of EXAFS spectra. The $\mathrm{d}^{9}$ electronic configuration of $\mathrm{Cu}$ (II) leads to the Jahn-Teller distortion of the first coordination shell. This structural distortion leads two distinct $\mathrm{Cu}-\mathrm{O}$ subshells, where the equatorial sub-shell dominates the EXAFS signal, but the axial sub-shell cannot be fitted reliably due to its anisotropic disorder (Cheah et al., 2000). The range of interatomic distances between $\mathrm{Cu}$ and first neighbors is also propagated to the second-shell neighbors. To best constrain the bonding environment of sorbed $\mathrm{Cu}$, we developed a list of diagnostic $\mathrm{Cu}-\mathrm{X}(\mathrm{X}=\mathrm{O}, \mathrm{Mn}, \mathrm{Cu})$ second-shell interatomic distances for a range of $\mathrm{Cu}-\mathrm{MnO}_{2}$ surface complexes (Fig. 2): For outer sphere (O.S.) surface complexes, we estimated the shortest-possible second-shell $\mathrm{Cu}-\mathrm{O}$ interatomic distances assuming a $0.135 \mathrm{~nm}$ ionic radius for $\mathrm{O}(-\mathrm{II})$ and a $0.27 \mathrm{~nm}$ distance between $\mathrm{O}$ atoms (Shannon, 1976; Xia et al., 1997). For inner-sphere surface complexes at vacancy sites and/or particle edges, we estimated the $\mathrm{Cu}-\mathrm{Mn}$ distances from sorption studies of $\mathrm{Cu}$ (Arai, 2011; Manceau et al., 2002; Sherman and Peacock, 2010) or other trace metals on birnessite (Duckworth et al., 2008; Manceau et al., 2007b; Villalobos et al., 2005). For Cu polymerization or precipitation, we obtained $\mathrm{Cu}-\mathrm{Cu}$ distances by fitting reference compounds or from reports of polynuclear $\mathrm{Cu}$ surface complexes (Cheah et al., 2000).

Shell-by-shell fits of the EXAFS spectra were made using SixPack (Webb, 2004) or Artemis (Ravel and Newville, 2005). Phase and amplitude functions were obtained with FEFF61 (Rhehr et al., 1992) for $\mathrm{Cu}(\mathrm{OH})_{2}(\mathrm{~s})$ (Downs and Hall-Wallace, 2003), geometryoptimized $\mathrm{Cu}-\mathrm{MnO}_{2}$ clusters with $\mathrm{Cu}$ coordinated to the surface oxygen atoms at a vacancy site (Kwon et al., 2013), and single scattering paths of varying interatomic distances to represent second-shell neighbors for $\mathrm{Cu}$ sorbed via outer-sphere $(\mathrm{X}=\mathrm{O})$, inner-sphere $(\mathrm{X}=$ $\mathrm{Mn})$ or precipitation mechanisms $(\mathrm{X}=\mathrm{Cu})$, following Fig. 2. The amplitude reduction factor $\left(S_{0}{ }^{2}\right)$ was set to 0.9 in all fits, based on analysis of the EXAFS spectra obtained from $50 \mathrm{mM}$ $\mathrm{CuCl}_{2}$ and $50 \mathrm{mM} \mathrm{Cu}$-EDTA solutions. Final fits were made in Artemis in $R$-space with all 
data sets fit simultaneously using a $k$-range of $2.5-12 \AA^{-1}$, which gives a spatial resolution of $\Delta R=\pi / 2 \Delta k=0.17 \AA$ (Kelly et al., 2008), $k$-weights of 2 and 3, and a Kaiser-Bessel window with a $d k$ value of $3 \AA^{-1}$. Fits of multiple $k$-weights simultaneously reduce errors in fitted parameters and correlations between variables (Kelly et al., 2008).

\section{Results}

3.1 Copper sorption. As shown by Fig. 3, Cu was sorbed extensively by $\delta-\mathrm{MnO}_{2}$ in suspensions equilibrated to $\mathrm{pH}$ values of $6(10 \mathrm{mM} \mathrm{NaCl}$ and $20 \mathrm{mM}$ MES buffer). Plots of $K_{d}$ against $q$ showed that $K_{d}$ extrapolated to a finite value as $q$ approached zero and tended to zero at a finite value of $q$ (Fig. 3, inset). A maximum surface excess value of $0.72(0.64-$ 0.83, $95 \%$ confidence interval) $\mathrm{mol} \mathrm{Cu} \mathrm{mol}^{-1} \mathrm{Mn}$ was determined from the $x$-intercepts of $K_{d}$ versus $q$ plots for $\delta-\mathrm{MnO}_{2}$. If each linear segment in the $K_{d}$ versus $q$ plots is assumed to correspond to a class of sorption sites with different affinities, the corresponding maximum surface excess values are $0.19(0.18-0.20)$ and $0.53(0.43-0.64) \mathrm{mol} \mathrm{Cu} \mathrm{mol}^{-1}$.

The sorption of $\mathrm{Cu}$ by $\delta-\mathrm{MnO}_{2}$ was accompanied by the concomitant accumulation of $\mathrm{Mn}(\mathrm{II})$ in solution (Fig._4). At the highest loadings (ca. $0.5-0.6 \mathrm{~mol} \mathrm{Cu} \mathrm{mol}^{-1} \mathrm{Mn}$ ), concentrations of 110 - $130 \mu \mathrm{M}$ Mn were measured in solution. These Mn(II) concentrations, which were adjusted by the fraction of $\mathrm{Mn}$ (II) released from $\mathrm{Cu}$-free suspensions $(28 \mu \mathrm{M} \mathrm{Mn}$ or $1.23 \%$ of the total $\mathrm{Mn}$ at $\mathrm{pH} 6.03$ ), represent about $5 \%$ of the total initial $\mathrm{Mn}$ in the solid phase. The $\mathrm{Mn}$ released to solution derives from $\mathrm{Mn}(\mathrm{II}, \mathrm{III})$ associated with the $\delta-\mathrm{MnO}_{2}$ particles. Although the unreacted $\delta-\mathrm{MnO}_{2}$ powder had an AMON of 4.0 and Na:Mn content of $26 \%$, the AMON value of $\delta-\mathrm{MnO}_{2}$ equilibrated to $\mathrm{pH} 6.0$ (10 mM NaCl, $20 \mathrm{mM}$ HEPES) decreased to 3.85 and the Na:Mn content to $13 \%$ before the addition of $\mathrm{Cu}(\mathrm{II})$. This decrease in AMON suggests that the buffer used to control solution $\mathrm{pH}$ may interact with the Mn oxide particles through $\mathrm{Mn}(\mathrm{IV})$ reduction. This $\mathrm{AMON}$ value indicates that $\delta-\mathrm{MnO}_{2}$ contains up to 
$15 \% \mathrm{Mn}(\mathrm{III})$ or $7 \% \mathrm{Mn}(\mathrm{II})$, which may be distributed within the $\mathrm{MnO}_{2}$ sheets or in the interlayer (Manceau et al., 2013). The decrease in the Na:Mn content is consistent with the increase in $\mathrm{H}^{+}$activity and accumulation of layer $\mathrm{Mn}(\mathrm{III})$ and interlayer $\mathrm{Mn}(\mathrm{II}, \mathrm{IIII})$ in $\delta$ $\mathrm{MnO}_{2}$ as $\mathrm{pH}$ is lowered from the synthesis $\mathrm{pH}$ of 8 to the experimental $\mathrm{pH}$ of 6 (Manceau et al., 2013).

The concentration of aqueous $\mathrm{Mn}$ increased in proportion to the $\mathrm{Cu}$ surface excess for $q<0.4 \mathrm{~mol} \mathrm{Cu} \mathrm{mol}{ }^{-1} \mathrm{Mn}$, with $1 \mathrm{~mol}$ of $\mathrm{Mn}$ measured in solution for every $7.4 \mathrm{~mol}$ of $\mathrm{Cu}$ sorbed $\left(R^{2}=0.97\right)$. Based on this correlation, we determined the apparent cation-exchange constant, $K_{\text {app }}$, for the reaction.

$$
\mathrm{Cu}(\mathrm{II})+\equiv \mathrm{Mn}(\mathrm{II}, \mathrm{III}) \leftrightarrow \mathrm{Mn}(\mathrm{II})+\equiv \mathrm{Cu}(\mathrm{II})
$$

by regressing $q /\left(c_{\mathrm{Cu}} / c_{\mathrm{Mn}(\mathrm{II})}\right)$ against $q$ for $q<0.4 \mathrm{~mol} \mathrm{Cu} \mathrm{mol}^{-1} \mathrm{Mn}($ Fig. A.2) following the approach described in Peña et al. (2010). On the left side of equation (2), both $\mathrm{Mn}(\mathrm{II})$ and $\mathrm{Mn}(\mathrm{III})$ are indicated as surface-bound species. However, $\mathrm{Mn}^{3+}$, which disproportionates readily to $\mathrm{Mn}(\mathrm{IV})$ and $\mathrm{Mn}(\mathrm{II})$ unless complexed by a high-affinity ligand (Morgan, 2000), is not included on the right-hand side of equation (2). The apparent cation-exchange constant of $1.67 \pm 0.80$, which is not statistically different from 1.0 , suggests no preference of $\delta-\mathrm{MnO}_{2}$ for neither $\mathrm{Cu}(\mathrm{II})$ nor $\mathrm{Mn}(\mathrm{II}, \mathrm{III})$ (Sposito, 2008).

3.2 X-ray absorption near edge structure spectra. The XANES spectra from experimental samples are plotted together with the spectra from $\mathrm{CuCl}_{2}(\mathrm{aq}), \mathrm{Cu}(\mathrm{OH})_{2}(\mathrm{~s})$ and $\mathrm{CuO}(\mathrm{s})$ in Fig. 5. The presence of $\mathrm{Cu}$ as $\mathrm{Cu}(\mathrm{II})$ is confirmed by the absorption edge position of $8998 \mathrm{eV}$ and very weak pre-edge feature around $8981 \mathrm{eV}$ (Kau et al., 1987). The shoulder in the XANES spectra near $8990 \mathrm{eV}$, manifest as distinct peaks near 8987 and $8993 \mathrm{eV}$ in the first derivative of the XANES spectra (Fig. 5b), indicates significant distortion of the $\mathrm{Cu}$ (II) polyhedron in the sorption samples. This feature arises from the destabilization of the $4 p_{z}$ orbitals that causes the elongation of the axial bonds relative to the equatorial ones (Alcacio et al., 2001; 
Frenkel et al., 2000; Garcia et al., 1989). In tetrahedral coordination, the pre-edge feature in the $\mathrm{Cu}$ K-edge XANES should show greater intensity and be shifted towards slightly lower energies (Dupont et al., 2002; Shimizu et al., 2001). The XANES spectra from the sorption samples show additional differences relative to the reference compounds as indicated by the arrowheads in Fig. 5a. The intensity of the shoulder near $9010 \mathrm{eV}$ in the sorption samples is intermediate to that in aqueous $\mathrm{Cu}(\mathrm{II})$ and the $\mathrm{Cu}$ solids. Furthermore, the shape and position of the oscillation around $9040 \mathrm{eV}$ in the XANES spectra from the $\delta-\mathrm{MnO}_{2}$ samples differ from that in $\mathrm{Cu}(\mathrm{OH})_{2}(\mathrm{~s})$. These differences between the experimental and reference XANES spectra support the adsorption rather than the precipitation of $\mathrm{Cu}(\mathrm{II})$ in the $\delta-\mathrm{MnO}_{2}$ samples.

3.3 Qualitative interpretation of the EXAFS spectra. The $\mathrm{Cu}$ K-edge EXAFS spectra and corresponding FTs obtained from $\delta-\mathrm{MnO}_{2}$ samples are presented in Fig. 6. The EXAFS spectra for samples with loadings ranging from 1 to $26 \%\left(\mathrm{~mol} \mathrm{Cu} \mathrm{mol}{ }^{-1} \mathrm{Mn}\right)$ show only small sample-to-sample variations. Principal component analysis (Toner et al., 2006) returns one component, which can describe $73 \%$ of the variance in the entire data set or $82 \%$ of the variance in the data set when $\mathrm{Cu}_{-} 01 \mathrm{a}$ and $\mathrm{Cu}_{-} 02 \mathrm{a}$ were excluded from the analysis due to high noise at large $k$-values. In Fig. 7, the EXAFS spectra from samples Cu_02b (Fig. 7A) and $\mathrm{Cu}_{-} 12 \mathrm{~b}($ Fig. $7 \mathbf{B})$ are overlain with the reference spectra from $\mathrm{Cu}^{2+}(\mathrm{aq}), \mathrm{Cu}$-biogenic $\mathrm{MnO}_{2}, \mathrm{Cu}(\mathrm{OH})_{2}(\mathrm{~s}), \mathrm{CuO}(\mathrm{s})$ and $\mathrm{Cu}\left(\mathrm{CO}_{3}\right)_{2} \mathrm{OH}(\mathrm{s})$. The EXAFS spectra from the sorption samples differ from both the EXAFS spectrum for $\mathrm{Cu}^{2+}(\mathrm{aq})$, which consists of one major frequency, and the EXAFS spectra for Cu-biogenic $\mathrm{MnO}_{2}$ and $\mathrm{Cu}(\mathrm{OH})_{2}(\mathrm{~s})$, which show distinct splitting of the oscillations around $8.0 \AA^{-1}$ and $10 \AA^{-1}$. The EXAFS spectra from the experimental samples also match poorly with those from $\mathrm{CuCO}_{3} \mathrm{OH}$ and $\mathrm{CuO}$. Target transform analysis (Toner et al., 2006) for all $\mathrm{Cu}$ minerals returned spoil values greater than 5, confirming the poor match between the EXAFS spectra from the reference $\mathrm{Cu}$ solids and the sorption samples. None of the reference compounds tested provides a close match to the 
experimental samples, suggesting that these phases were not present in the samples at fractions above the detection limit of EXAFS spectroscopy.

The FTs of the EXAFS spectra (Fig. 6b) show a major peak near $1.5 \AA(R+d R)$, corresponding to the first shell of oxygen atoms surrounding $\mathrm{Cu}$. The absence of a prominent second-shell peak near $3 \AA(R+d R)$ contrasts the FT EXAFS spectra from $\mathrm{Cu}-\delta-\mathrm{MnO}_{2}[\mathrm{pH}$ 4, (Manceau et al., 2007b)], Cu-biogenic $\mathrm{MnO}_{2}$ [pH 6, (Peña, 2009)], and Ni and $\mathrm{Zn}-\mathrm{MnO}_{2}$ [pH 4 - 8, (Manceau et al., 2007b; Peacock and Sherman, 2007b; Peña et al., 2010; Toner et al., 2006)] where the metal adsorbs mainly as a TCS species at the vacancy sites. Instead, the FTs of our EXAFS spectra show two small second-shell peaks at ca. 2.5 and $3.5 \AA(R+d R)$ that are separated by $0.4-0.5 \AA$. Due to geometric constraints, a second-shell O atom could be no closer than about $3.4 \AA$ (Fig. 2). Oxygen second neighbors thus can only contribute amplitude to the $2^{\text {nd }}$ of these two second-shell peaks. Copper is unlikely to contribute amplitude to the $2^{\text {nd }}$ second-shell peak based on the $\mathrm{Cu}-\mathrm{Cu}$ distances in oxide and hydroxide minerals, which range from 2.91 to $3.10 \AA$ (Cheah et al., 2000). Manganese, however, could be present over the entire range of 2.5 and $3.5 \AA(R+d R)$. At distances greater than $3.6 \AA(R$ $+d R)$, small amplitude peaks are present but we cannot ascertain whether they arise from scattering from neighboring atoms or artifacts from Fourier transformation.

The preceding qualitative analysis provides three insights into the sorption mechanism of $\mathrm{Cu}$ equilibrated with $\delta-\mathrm{MnO}_{2}$ at $\mathrm{pH}$ 6: 1) a discreet $\mathrm{Cu}$ precipitate is unlikely; 2) $\mathrm{Cu}-\mathrm{TCS}$ complexes are not a major surface species; and 3) $\mathrm{Cu}$ appears to show no preference in the average bonding environment at low surface loading relative to high surface loading.

3.4 Shell-by-shell fits of EXAFS spectra. We fit the first-shell peak in the FT of the EXAFS spectra with $3.6-4.0$ oxygen atoms at $1.94 \AA$ (Table 2). The $C N$ for the $\mathrm{Cu}-\mathrm{O}$ shell at $1.94 \AA$ was higher for samples with lower loadings and lower $\mathrm{pH}$ values. The decrease in $C N$ as the 
$\mathrm{Cu}$ loading increases indicates an increase in the average structural disorder around $\mathrm{Cu}$, which is consistent with an increase in the number of surface complex geometries.

While we expect the presence of one or two axial ligands in the first coordination shell, they are far from the $\mathrm{Cu}$ center and have high structural disorder (Cheah et al., 2000). Manceau et al. (2002) obtained an improved fit and more physically reasonable model by adding $1-2$ oxygen atoms at $2.23 \AA$, along with 4 the oxygen atoms at $1.96 \AA$. Consistent with this result, the $6 \mathrm{eV}$ separation between the $\alpha$ - and $\beta$-peaks in the $1^{\text {st }}$ derivative of the XANES spectra (Fig. 5b) indicates that the axial ligand(s) are located at about $1.9+0.4 \AA$ or $2.3 \AA$ (Frenkel et al., 2000). We cannot confirm whether $\mathrm{Cu}$ has one or two axial ligands but, in principle, both outcomes are reasonable because $\mathrm{Cu}$ in aqueous solution prefers a 5-fold elongated square pyramidal coordination that is likely to be competitive with a 6-fold distorted octahedral coordination (Bryantsev et al., 2008; Frenkel and Korshin, 2001).

To test the coordination geometries shown in Fig. 2, we fit the ca. $2.0 \AA(R+d R)$ peak with $\mathrm{Cu}-\mathrm{Mn}$ and $\mathrm{Cu}-\mathrm{Cu}$ paths and the ca. $3.5 \AA(R+d R)$ peak with $\mathrm{Cu}-\mathrm{Mn}$ and $\mathrm{Cu}-\mathrm{O}$ scattering paths (Figs. 8 and 9). Fits to the ca. $2.0 \AA$ peak using either $\mathrm{Cu}-\mathrm{Cu}$ or $\mathrm{Cu}-\mathrm{Mn}$ scattering paths yielded similar results in terms of the $R$-factor and uncertainties in estimated parameters (Table 2). However, the optimized distances representing edge-sharing and corner-sharing linkages between $\mathrm{Cu}$ and $\mathrm{Mn}$ polyhedra varied slightly depending on the backscatter included in the fit: $\mathrm{Cu}-\mathrm{Cu} 2.88 \AA$ or $\mathrm{Cu}-\mathrm{Mn} 2.90 \AA$ with $\mathrm{Cu}-\mathrm{Mn}$ at $3.39 \AA$. Our attempts to include a $\mathrm{Cu}-\mathrm{O}$ path to fit $2^{\text {nd }}$ second-shell peak were not successful, suggesting that $\mathrm{Cu}-\mathrm{Cu} / \mathrm{Mn}$ scattering contribute most of the amplitude to the second-shell peaks. Finally, the fitted second-shell $C N s$, which ranged from $0.50 \pm 0.23$ to $1.47 \pm 0.39$, indicate that on average $\mathrm{Cu}$ has few near neighbors.

\section{Discussion}




\subsection{Copper coordination environment}

The XANES spectra obtained from $\mathrm{Cu}$ sorbed $\delta-\mathrm{MnO}_{2}$ indicate that $\mathrm{Cu}$ is present as Jahn-Teller distorted $\mathrm{Cu}(\mathrm{II})$ with either one or two axial ligands. In our analysis of the EXAFS spectra, we fit approximately $4 \mathrm{Cu}$ atoms with a low Debye Waller factor $(0.005 \pm$ $0.0003 \AA^{2}$ ), indicating relatively low local structural disorder in the four $\mathrm{Cu}-\mathrm{O}$ bond distances. Presumably, these four $\mathrm{Cu}-\mathrm{O}$ bonds are the equatorial bonds of the Jahn-Teller distorted $\mathrm{Cu}$ polyhedron. The $\mathrm{Cu}-\mathrm{O}$ interatomic distance of $1.94 \pm 0.002 \AA$ found for our samples is slightly shorter by $0.01-0.02 \AA$ relative to the $\mathrm{Cu}-\mathrm{O}$ distance reported for $\mathrm{Cu}(\mathrm{OH})_{2}$ and $\mathrm{Cu}$ sorbed $\delta-\mathrm{MnO}_{2}$ samples (Arai, 2011; Cheah et al., 2000; Manceau et al., 2002). A Cu-O distance of $1.94 \AA$ was observed for $\mathrm{Cu}$ complexed by NOM (Manceau and Matynia, 2010). This ideal or strain-free metal-ligand bond length is achieved when $\mathrm{Cu}$ lies in the plane formed by two ring chelates (Manceau and Matynia, 2010). By analogy, this result together with the low fit-derived $C N$ s for the $\mathrm{Cu}-\mathrm{Cu} / \mathrm{Mn}$ shells $(\mathrm{CN}<2)$ and the similarity in fits where $\mathrm{Cu}$ or $\mathrm{Mn}$ was used as the second-shell backscatter suggests that at least a fraction of the total $\mathrm{Cu}$ sorbs as $\mathrm{Cu}$-dimers at the particle edges in the DES geometry, with one pair of equatorial oxygen atoms in $\mathrm{Cu}$ coordinated to $\mathrm{Cu}$ and the other pair coordinated to $\mathrm{Mn}$.

The Fourier transformed $\mathrm{Cu}$ K-edge EXAFS spectra acquired from $\delta-\mathrm{MnO}_{2}$ displayed two small second-shell peaks due to scattering from $\mathrm{Mn}$ and $\mathrm{Cu}$ second-shell neighbors. We attempted to establish the polyhedral connectivity between $\mathrm{Cu}$ and $\mathrm{Mn}$ polyhedra (Fig. 2) based on the $\mathrm{Cu}-\mathrm{Mn}$ and $\mathrm{Cu}-\mathrm{Cu}$ interatomic distances obtained from fitting the EXAFS spectra. However, for the ca. $2.0 \AA(R+d R)$ FT peak, the goodness of fit criteria and uncertainties in fitted parameters were similar regardless of whether $\mathrm{Cu}$ or $\mathrm{Mn}$ was used as the backscattering atom. In addition, in all fits the coordination numbers of the $\mathrm{Cu}-\mathrm{Cu}$ and/or $\mathrm{Cu}-\mathrm{Mn}$ shells ranged from $0.52 \pm 0.14$ to $1.47 \pm 0.38$, with Debye-Waller factors less than $0.008 \AA^{2}$. These structural parameters together with the low amplitude of FT peaks at $R+d R$ 
$>4 \AA$ suggest that on average $\mathrm{Cu}$ has a relatively small number of $\mathrm{Mn}$ and $\mathrm{Cu}$ near neighbors. Evidently, the surface complex geometries are not well defined. However, our data indicate that the formation of a discreet $\mathrm{Cu}$ precipitate and the incorporation of $\mathrm{Cu}$ at vacancy sites are unlikely.

Several lines of evidence indicate that the formation of a discreet precipitate is unlikely. First, the XANES spectra show distinct differences in the samples versus the $\mathrm{Cu}$ precipitates, especially in the oscillation near $9040 \mathrm{eV}$. Second, the fitted $\mathrm{Cu}-\mathrm{Cu}$ distance of $2.88 \pm 0.006 \AA$ for the samples is shorter by $0.03-0.08 \AA$ than the $\mathrm{Cu}-\mathrm{Cu}$ distances observed in $\mathrm{Cu}$ solids such as $\mathrm{Cu}(\mathrm{OH})_{2}(\mathrm{~s})$ and $\mathrm{CuO}(\mathrm{s})$. Target transform analysis showed that the EXAFS spectra from various $\mathrm{Cu}$ solids could not be reconstructed based on the principle components identified in the data set. Third, the EXAFS spectra measured from the sorption samples were similar irrespective of the $\mathrm{Cu}$ surface loading, even at the lowest surface loading $\left(\mathrm{Cu} \_01 \mathrm{a}\right)$ where the saturation index with respect to the $\mathrm{Cu}$ solids ranged from 0.01 0.36 .

Our EXAFS spectra also do not provide strong evidence in support of the incorporation of $\mathrm{Cu}$ at vacancy sites. In a previous study, a small extent of $\mathrm{Cu}$ incorporation (ca. $20 \%$ of the total sorbed $\mathrm{Cu}$ or $0.01 \mathrm{~mol} \mathrm{Cu} \mathrm{mol}^{-1} \mathrm{Mn}$ ) has been reported to occur at $\mathrm{pH} 8$ (Sherman and Peacock, 2010). However, the Cu K-edge EXAFS spectrum acquired from a sample at $\mathrm{pH} 8$ was rather similar to the EXAFS spectrum acquired from a sample at $\mathrm{pH} 4$, where $\mathrm{Cu}$ was assigned to bind exclusively to vacancy sites as $\mathrm{Cu}$-TCS. In the current study, in addition to the low fitted $C N$ s and to the lack of structure at $R$-values greater than $3 \AA$, we exclude the significant incorporation of $\mathrm{Cu}$ at vacancy sites based on the strongly distorted first shell of $\mathrm{Cu}^{2+}$ polyhedron and the highly-ordered bonding environment imposed by the triangular cavity formed by the three surface oxygen atoms at a vacancy site. Our interpretation is consistent with a recent DFT study, which showed that $\mathrm{Cu}$ incorporation 
strongly inhibited the Jahn-Teller distortion of $\mathrm{Cu}$ and thus destabilized this species relative to the $\mathrm{Cu}$-TCS species.

Instead, we suggest that $\mathrm{Cu}$ forms multiple surface species, including inner-sphere complexes and dimeric or polynuclear surface species (i.e., containing multiple $\mathrm{Cu}$ atoms). The large measured surface excess values support the formation of $\mathrm{Cu}$ dimers or polynuclear surface species. In addition, these complexes should occur in all samples based on the similarity in the $\mathrm{Cu}$ K-edge EXAFS spectra at the lowest and highest surface loadings.

If $\mathrm{Cu}$ dimers sorbed at the $\delta-\mathrm{MnO}_{2}$ particle edges in an edge-sharing configuration with respect to $\mathrm{Mn}$ octahedra, then both $\mathrm{Cu}$ and $\mathrm{Mn}$ near-neighbors would be located at similar interatomic distances and photoelectron backscattering from both elements would contribute to the $2.0 \AA(R+d R)$ peak in the FT-EXAFS spectra. When a Cu shell was fit to the second-shell peak at ca. $2.5 \AA(R+d R)$, we obtained a $\mathrm{Cu}-\mathrm{Cu}$ distance of $2.88 \pm 0.006 \AA$. This distance is within $0.03-0.08 \AA$ of the $\mathrm{Cu}-\mathrm{Cu}$ distances observed in $\mathrm{Cu}(\mathrm{OH})_{2}$ and $\mathrm{CuO}$. The contracted $\mathrm{Cu}-\mathrm{Cu}$ distance in our sorption samples may be caused by the underlying mineral substrate, which is known to influence the distance between $\mathrm{Cu}$ atoms in polynuclear surface complexes (Cheah et al., 2000; Karthikeyan et al., 1999; Morton et al., 2001; Peacock and Sherman, 2004; Rodda et al., 1996; Strawn et al., 2004). When a Mn shell was fit to this peak, we obtained a Cu-Mn distance of $2.90 \pm 0.006 \AA$. This $\mathrm{Cu}-\mathrm{Mn}$ distance is similar to the average Mn-Mn (2.87 $⿱$ ) and Ni-Mn (2.86 ̊) distances between edge-sharing octahedra in birnessite (Peña et al., 2010; Villalobos et al., 2006).

The longer second-shell interatomic distance of $3.39 \AA$ does not appear in $\mathrm{Cu}$ solids (Cheah et al., 2000). Therefore, this distance likely arises from Mn second neighbors. The average $\mathrm{Cu}-\mathrm{Mn}$ distance of $3.39 \AA$ may due to the adsorption of $\mathrm{Cu}$ at vacancy sites. Manceau et al. (2002) and Sherman and Peacock (2010) each collected an EXAFS spectrum from samples prepared at $\mathrm{pH} 4$ with loadings of $0.156 \mathrm{~mol} \mathrm{Cu} \mathrm{mol}^{-1} \mathrm{Mn}$ and $0.07 \mathrm{~mol} \mathrm{Cu}$ 
$\mathrm{mol}^{-1} \mathrm{Mn}$, respectively. Manceau et al. (2002) proposed a Jahn-Teller distorted octahedral TCS complex with 5.4 Mn atoms fitted at $3.43 \AA$, whereas Sherman and Peacock (2010) suggested a 4-coordinate TCS complex with $3 \mathrm{Mn}$ atoms fixed at $3.39 \AA$ and $3 \mathrm{Mn}$ atoms fixed at $3.43 \AA$. Similar to these Cu-Mn distances, Arai (2011) fitted $2-3 \mathrm{Mn}$ atoms at 3.42 $\AA$ in samples where $\mathrm{Cu}$ was adsorbed in kaolinite-birnessite mixtures with a maximum loading of $0.02 \mathrm{~mol} \mathrm{Cu} \mathrm{mol}{ }^{-1} \mathrm{Mn}\left(33 \mathrm{~m}^{2} \mathrm{~g}^{-1}\right.$ specific surface area) and a solution $\mathrm{pH}$ value of 4 or 6 . Geometry optimizations of $\mathrm{Cu}$-TCS with $\mathrm{Cu}$ in six-fold coordination (octahedral) showed average $\mathrm{Cu}-\mathrm{O}$ and $\mathrm{Cu}-\mathrm{Mn}$ distances of $2.02 \AA$ and $3.48 \AA$, whereas $\mathrm{Cu}$-TCS in fourfold coordination (tetrahedral) with two hydrogen-bonded water molecules showed average $\mathrm{Cu}-\mathrm{O}$ and $\mathrm{Cu}-\mathrm{Mn}$ distances of $1.95 \AA$ and $3.40 \AA$ (Kwon et al., 2013). The geometryoptimized structures for both $\mathrm{Cu}$-TCS with $\mathrm{Cu}$ in six or four-fold coordination showed highly asymmetric distributions of near-neighbor distances and similar relative stabilities in terms of the total energy of the complex (Kwon et al., 2013). Thus, both coordination geometries may be possible at the vacancy sites.

\subsection{Copper sorption capacity}

The $\delta-\mathrm{MnO}_{2}$ used in this study showed extensive sorption of $\mathrm{Cu}$. The measured surface excess values of $\mathrm{Cu}$ on birnessite agree with previous reports. For example, at $\mathrm{pH} 4$ 4.5, surface excess values of $0.13-0.14 \mathrm{~mol} \mathrm{Cu} \mathrm{mol}^{-1} \mathrm{Mn}$ were obtained for birnessite (McKenzie, 1970; Traina and Doner, 1985b; Wang et al., 2012), whereas at pH 6, in the presence of equimolar solutions of $\mathrm{Cu}(\mathrm{II})$ and $\mathrm{Co}(\mathrm{II})$, a surface excess of $0.39 \mathrm{~mol} \mathrm{Cu} \mathrm{mol}^{-1}$ Mn was observed (Traina and Doner, 1985b). In addition, comparable surface excess values ranging from $0.22-0.31 \mathrm{~mol} \mathrm{~Pb} \mathrm{~mol}{ }^{-1} \mathrm{Mn}$ have been reported for $\mathrm{Pb}$ sorption by $\delta-\mathrm{MnO}_{2}$ at pH 5 - 6 (Nelson et al., 1999; Villalobos et al., 2005). The surface excess values reported generally increased with the specific surface area of birnessite used, which is consistent with 
the increasing proportion of edge sites with decreasing particle size (Villalobos et al., 2005). For example, Catts and Langmiur (1986) showed that as the specific surface area of $\delta-\mathrm{MnO}_{2}$ increased from 143 to $290 \mathrm{~m}^{2} \mathrm{~g}^{-1}$, the surface excess increased from 0.07 to $0.12 \mathrm{~mol} \mathrm{Cu} \mathrm{mol}{ }^{-}$

1 Mn. However, Wang et al. (2012) showed that variations in the average manganese oxidation number influenced adsorption capacity more strongly than specific surface area, thus the $\mathrm{Mn}(\mathrm{III})$ content and distribution within the $\mathrm{MnO}_{2}$ structure must be considered in order to assess correctly the relative importance of vacancy versus edge sites for metal sorption by birnessite.

Concomitant with the adsorption of $\mathrm{Cu}$, up to $5 \%$ of the total $\mathrm{Mn}$ initially in the solid phase was measured in solution as $\mathrm{Mn}(\mathrm{II})$, after correction for any $\mathrm{Mn}$ released from the $\mathrm{Cu}-$ free experiments. Aqueous $\mathrm{Mn}$ derives from adsorbed lower-valent $\mathrm{Mn}$ that is readily displaced by $\mathrm{Cu}(\mathrm{II})$ (McKenzie, 1970; Traina and Doner, 1985a, b). The measured AMON value of 3.85 indicates that $\delta-\mathrm{MnO}_{2}$ equilibrated with $10 \mathrm{mM} \mathrm{NaCl}$ and $20 \mathrm{mM}$ MES buffer contains up to $15 \% \mathrm{Mn}(\mathrm{III})$ or $7 \% \mathrm{Mn}$ (II) before $\mathrm{Cu}$ addition. Thus, at the maximum surface loadings, $30-70 \%$ of the lower-valent $\mathrm{Mn}$ has been replaced by $\mathrm{Cu}$. While $\mathrm{Mn}(\mathrm{III})$ is assumed to migrate from layer to interlayer sites as vacancies are generated (Manceau et al., 2013), it is also plausible that some lower valent $\mathrm{Mn}$ is located at the particle edges.

\subsection{Distribution of $\mathrm{Cu}$ among surface sites}

Based on our fit-derived $C N \mathrm{~s}$ normalized to the ideal $C N$ of the $\mathrm{Cu}-\mathrm{Mn}$ shell characteristic for the TCS complex, and based on the correlation between the Mn(II) concentration in solution and the $\mathrm{Cu}$ surface excess that may arise from $\mathrm{Cu}-\mathrm{Mn}$ exchange at vacancy sites, we suggest that $15-24 \%$ of the total $\mathrm{Cu}$ adsorbed or $0.04-0.06 \mathrm{~mol} \mathrm{Cu} \mathrm{mol}^{-1}$ Mn may be present as $\mathrm{Cu}$-TCS. The remaining $\mathrm{Cu}(76-85 \%)$ would be adsorbed at the $\delta$ $\mathrm{MnO}_{2}$ particle edges. The fractional contribution of $\mathrm{Cu}$-TCS species corresponds to a 0.06 
mol Cu mol${ }^{-1} \mathrm{Mn}$ loading in the highest loading sample studied EXAFS spectroscopy. This loading is consistent with the moderate vacancy content reported for $\delta-\mathrm{MnO}_{2}$ (Villalobos et al., 2013; Manceau et al., 2013).

The $\mathrm{Cu}$-TCS loading estimated above represents the upper-limit contribution from $\mathrm{Cu}$-TCS species because the $\mathrm{Cu}-\mathrm{Mn}$ shell at $3.39 \AA$ may also reflect $\mathrm{Cu}$ or $\mathrm{Cu}$ dimers adsorbed at the $\delta-\mathrm{MnO}_{2}$ particle edges. For example, a $\mathrm{Cu}$ atom coordinated to two singlycoordinated oxygen atoms (e.g., $\mathrm{Cu}-\mathrm{DCS}$ ) may have a $\mathrm{Cu}-\mathrm{Mn}$ interatomic distance similar to the $\mathrm{Cu}-\mathrm{Mn}$ distance in the $\mathrm{Cu}$-TCS complex, as proposed for Ni-TCS and Ni-DCS species (Manceau et al., 2007b). In addition, Kwon et al. (2010) showed that the metal-Mn distances at the particle edges can overlap with the metal-Mn distances of complexes formed at vacancy sites.

The relative proportions of $\mathrm{Cu}$ adsorbed at vacancy sites and particle edges can also be estimated by considering the structure and size of $\delta-\mathrm{MnO}_{2}$ particles. A vacancy content ranging from $6-11 \%$ has been proposed for $\delta-\mathrm{MnO}_{2}$ based on modeling of $\mathrm{X}$-ray diffraction and high energy X-ray scattering data (Villalobos et al., 2006; Manceau et al., 2013). However, the "true" vacancy content is likely to be smaller because these estimates do not consider explicitly the under-coordinated Mn atoms at the particle edges (Grangeon et al., 2008; Villalobos et al., 2006). Using the 2 - 4 nm particle size obtained from HR-TEM (Fig. 1), we estimated that the proportion of binding sites at the particle edges, normalized to monovalent charges following Villalobos et al. (2005) is greater than the proportion of vacancy sites by at least one order of magnitude. Thus, our identification of the particle edges as the dominant reactive sites from EXAFS spectroscopy is reasonable in terms of surface site density and particle size.

Assuming that $\mathrm{Cu}$ adsorbs as dimers and assuming an approximate site density of 18 sites $\mathrm{nm}^{-2}$ (Catts and Langmuir, 1986) or $1.5 \times 10^{-3}$ mol sites $\mathrm{L}^{-1}$ for a $\delta-\mathrm{MnO}_{2}$ suspension 
containing $0.2 \mathrm{~g} \mathrm{~L}^{-1}$ and a specific surface area of $254 \mathrm{~m}^{2} \mathrm{~g}^{-1}$, we estimated that $\mathrm{Cu}$ occupies $0.7-17 \%$ of all surface sites on $\delta-\mathrm{MnO}_{2}$ in samples with loadings of 0.01 to $0.26 \mathrm{~mol} \mathrm{Cu}$ $\mathrm{mol}^{-1} \mathrm{Mn}$. If the loading was adjusted to account for the fraction of $\mathrm{Cu}$ that may adsorb as a TCS complex at vacancy sites, then $\mathrm{Cu}$ would occupy ca. $14 \%$ of the remaining surface sites in $\delta-\mathrm{MnO}_{2}$ at the highest loading studied by EXAFS spectroscopy $\left(0.26 \mathrm{~mol} \mathrm{Cu} \mathrm{mol}^{-1} \mathrm{Mn}\right)$. For particles with a 2 - 4 nm diameter (i.e., 20 - $40 \%$ of the Mn atoms at the particle edges), it is reasonable to have up to $20 \%$ of the reactive surface sites located at the particle edges. At the $q_{\max }$ value of $0.72 \mathrm{~mol} \mathrm{Cu} \mathrm{m^{-1 }} \mathrm{Mn}$, we estimate that $\mathrm{Cu}$ would occupy ca. $46 \%$ of all surface sites in $\delta-\mathrm{MnO}_{2}$ and that these reactive surface sites would be located dominantly at the particle edges. In contrast, assuming that only vacancy sites were reactive, Sherman and Peacock (2010) estimated a maximum sorption capacity of $0.013 \mathrm{~mol} \mathrm{Cu} \mathrm{mol}^{-1} \mathrm{Mn}$ based on the measured specific surface area of $107 \mathrm{~g} \mathrm{~m}^{-2}$ and estimate of 2.22 vacancies per $\mathrm{nm}^{2}$. Their measured a surface excess of $0.068 \mathrm{~mol} \mathrm{Cu} \mathrm{mol}^{-1} \mathrm{Mn}$ suggest that either the reactive surface area is not well approximated by specific surface area or that additional binding sites are involved in $\mathrm{Cu}$ sorption. The results in this study help to resolve this paradox.

\subsection{Environmental implications}

The manganese oxide used in the study, $\delta-\mathrm{MnO}_{2}$, has been proposed as a synthetic analog for birnessite found in natural environments (Villalobos et al., 2003). The maximum sorption capacity of $0.72 \mathrm{~mol} \mathrm{Cu} \mathrm{mol}{ }^{-1} \mathrm{Mn}(\mathrm{pH}$ 6), derived from plots of the distribution coefficient against surface excess, greatly exceeds the vacancy content expected for birnessite minerals. Our EXAFS analysis shows that $\mathrm{Cu}$ has a strong proclivity for adsorbing on the edge surfaces of nanoparticulate birnessite. The large tendency of $\mathrm{Cu}$ to sorb at the edges can be rationalized in terms of its Jahn-Teller distorted coordination and the ease with which it dimerizes. Both of these properties render the adsorption of $\mathrm{Cu}$ to geometrically-constrained 
sorption sites on the basal surface of $\mathrm{MnO}_{2}$ (i.e., triangular cavity formed by three surface oxygen atoms at a vacancy site) less favorable than adsorption at edge surface sites. For these same reasons, $\mathrm{Cu}$ may sorb more favorably at the particle edges than trace metals such as $\mathrm{Ni}$ and $\mathrm{Zn}$, which display significantly less distortion in the first coordination shell relative to $\mathrm{Cu}^{2+}$ and do not tend to polymerize. Nonetheless, $\mathrm{Ni}$ and $\mathrm{Zn}$ adsorption at edge surfaces may occur under conditions where vacancy sites are not available for sorption or where an overwhelming fraction of the reactive surface sites are located at the particle edges. In summary, the contribution of the edge surfaces to metal sorption by birnessite will be controlled by i) the preferred bonding geometry of the metal cation, ii) the relative proportions of edge to vacancy surface sites and iii) the presence of competing ligands that may block surface sites at the particle edges (e.g., organic ligands present in the biofilm matrix surrounding biogenic birnessite particles). Our findings suggest that in the absence of a biofilm matrix and/or in the case of vanishingly small particles, metal sorption at birnessite particle edges may be the dominant mode of metal attenuation.

\section{Acknowledgements}

This research was supported by the Office of Basic Energy Sciences of the U.S. Department of Energy under Contract No. DE-AC02-05CH11231. HR-TEM images were acquired at the National Center for Electron Microscopy at Lawrence Berkeley National Laboratory. J. Peña acknowledges support from the Sandoz Family Foundation. Portions of this research were carried out at the Stanford Synchrotron Radiation Lightsource, a national user facility operated by Stanford University on behalf of the U.S. Department of Energy, Office of Basic Energy Sciences.

\section{References}


Alcacio, T.E., Hesterberg, D., Chou, J.W., Martin, J.D., Beauchemin, S., Sayers, D.E., 2001. Molecular scale characteristics of $\mathrm{Cu}$ (II) bonding in goethite-humate complexes. Geochim. Cosmochim. Acta 65, 1355-1366.

Arai, Y., 2011. Aqueous interfacial chemistry of kaolinite for the removal of $\mathrm{Cu}$ (II) in the presence of birnessite: Kinetic and spectroscopic studies. Appl. Clay Sci. 53, 572-580.

Bargar, J.R., Fuller, C.C., Marcus, M.A., Brearley, A.J., De la Rosa, M.P., Webb, S.M., Caldwell, W.A., 2009. Structural characterization of terrestrial microbial $\mathrm{Mn}$ oxides from Pinal Creek, AZ. Geochim. Cosmochim. Acta 73, 889-910.

Bradl, H.B., 2005. Heavy Metals in the Environment, Interface Science and Technology. Elsevier Academic Press, New York, p. 269.

Bryantsev, V.S., Diallo, M.S., van Duin, A.C.T., Goddard, W.A., III, 2008. Hydration of copper(II): New insights from density functional theory and the COSMO solvation model. Journal of Physical Chemistry A 112, 9104-9112.

Catts, J.G., Langmuir, D., 1986. Adsorpiton of $\mathrm{Cu}, \mathrm{Pb}$ and $\mathrm{Zn}$ by $\delta-\mathrm{MnO}_{2}$ : applicability of the site binding-surface complexation model. Appl. Geochem. 1, 25-264.

Cheah, S.F., Brown, G.E., Parks, G.A., 2000. XAFS study of $\mathrm{Cu}$ model compounds and $\mathrm{Cu}^{2+}$ sorption products on amorphous $\mathrm{SiO}_{2}$, gamma- $\mathrm{Al}_{2} \mathrm{O}_{3}$, and anatase. Am. Mineral. 85, 118-132.

Davies-Colley, R.J., Nelson, P.O., Williamson, K.J., 1984. Copper and cadmium uptake by estuarine sedimentary phases. Environ. Sci. Technol. 18, 491-499.

Downs, R.T., Hall-Wallace, M., 2003. The American mineralogist crystal structure database. Am. Mineral. 88, 247-250.

Duckworth, O.W., Bargar, J.R., Sposito, G., 2008. Sorption of ferric iron from ferrioxamine $\mathrm{B}$ to synthetic and biogenic layer type manganese oxides. Geochim. Cosmochim. Acta 72, 3371-3380.

Duckworth, O.W., Sposito, G., 2007. Siderophore-promoted dissolution of synthetic and biogenic layer-type Mn oxides. Chem. Geol. 242, 497-508.

Dupont, L., Guillon, E., Bouanda, J., Dumonceau, J., Aplincourt, M., 2002. EXAFS and XANES studies of retention of copper and lead by a lignocellulosic biomaterial. Environmental Science \& Technology 36, 5062-5066.

Frenkel, A.I., Korshin, G.V., 2001. Studies of $\mathrm{Cu}(\mathrm{II})$ in soil by X-ray absorption spectroscopy. Canadian Journal of Soil Science 81, 271-276. 
Frenkel, A.I., Korshin, G.V., Ankudinov, A.L., 2000. XANES study of Cu2+-binding sites in aquatic humic substances. Environmental Science \& Technology 34, 2138-2142.

Garcia, J., Benfatto, M., Natoli, C.R., Bianconi, A., Fontaine, A., Tolentino, H., 1989. The quantitative Jahn-Teller distortion of the $\mathrm{Cu}^{2+}$ site in aqueous-solution by XANES spectroscopy. Chem. Phys. 132, 295-307.

Grangeon, S., Lanson, B., Lanson, M., Manceau, A., 2008. Crystal structure of Ni-sorbed synthetic vernadite: a powder X-ray diffraction study. Mineralogical Magazine 72, 12791291.

Grangeon, S., Lanson, B., Miyata, N., Tani, Y., Manceau, A., 2010. Structure of nanocrystalline phyllomanganates produced by freshwater fungi. Am. Mineral. 95, 16081616.

Hochella, M.F., Kasama, T., Putnis, A., Putnis, C.V., Moore, J.N., 2005. Environmentally important, poorly crystalline Fe/Mn hydrous oxides: Ferrihydrite and a possibly new vernadite-like mineral from the Clark Fork River Superfund Complex. Am. Mineral. 90, 718724.

Jenne, E.A., 1968. Controls on $\mathrm{Mn} \mathrm{Fe} \mathrm{Co} \mathrm{Ni} \mathrm{Cu}$ and $\mathrm{Zn}$ concentrations in soils and water: The significant role of hydrous Mn and Fe Oxides. Advances in Chemistry Series, 337-387.

Karthikeyan, K.G., Elliott, H.A., Chorover, J., 1999. Role of surface precipitation in copper sorption by the hydrous oxides of iron and aluminum. J. Colloid Interface Sci. 209, 72-78.

Kau, L.S., Spirasolomon, D.J., Pennerhahn, J.E., Hodgson, K.O., Solomon, E.I., 1987. X-Ray absorption-edge determination of the oxidation-state and coordination-number of copper: Application to the type-3 Site in Rhus vernicifera laccase and its reaction with oxygen. J. Am. Chem. Soc. 109, 6433-6442.

Kelly, S.D., Hesterberg, D., Ravel, B., 2008. Analysis of Soils and Minerals Using X-ray Absorption Spectroscopy, in: Ulrey, A.L., Drees, R.L. (Eds.), Methods of Soil Analysis, Part 5-Mineralogical Methods. Soil Science Society of America, Madison.

Klee, R.J., Graedel, T.E., 2004. Elemental cycles: A status report on human or natural dominance. Annual Review of Environment and Resources 29, 69-107.

Kwon, K.D., Refson, K., Sposito, G., 2010. Surface complexation of Pb(II) by hexagonal birnessite nanoparticles. Geochim. Cosmochim. Acta 74, 6731-6740.

Kwon, K.D., Refson, K., Sposito, G., 2013. Understanding the trends in transition metal sorption by vacancy sites in birnessite. Geochim. Cosmochim. Acta 101, 222-232.

Learman, D.R., Voelker, B.M., Vazquez-Rodriguez, A.I., Hansel, C.M., 2011. Formation of manganese oxides by bacterially generated superoxide. Nature Geoscience 4, 95-98. 
Lingane, J.J., Karplus, R., 1946. NEW METHOD FOR DETERMINATION OF MANGANESE. Industrial and Engineering Chemistry-Analytical Edition 18, 191-194.

Manceau, A., Kersten, M., Marcus, M.A., Geoffroy, N., Granina, L., 2007a. Ba and Ni speciation in a nodule of binary Mn oxide phase composition from Lake Baikal. Geochim. Cosmochim. Acta 71, 1967-1981.

Manceau, A., Lanson, B., Drits, V.A., 2002. Structure of heavy metal sorbed birnessite. Part III: Results from powder and polarized extended X-ray absorption fine structure spectroscopy. Geochim. Cosmochim. Acta 66, 2639-2663.

Manceau, A., Lanson, M., Geoffroy, N., 2007b. Natural speciation of Ni, Zn, Ba, and As in ferromanganese coatings on quartz using X-ray fluorescence, absorption, and diffraction. Geochim. Cosmochim. Acta 71, 95-128.

Manceau, A., Marcus, M.A., Grangeon, S., Lanson, M., Lanson, B., Gaillot, A.C., Skanthakumar, S., Soderholm, L., 2013. Short-range and long-range order of phyllomanganate nanoparticles determined using high-energy X-ray scattering. J. Appl. Crystallogr. 46, 193-209.

Manceau, A., Matynia, A., 2010. The nature of $\mathrm{Cu}$ bonding to natural organic matter. Geochim. Cosmochim. Acta 74, 2556-2580.

Marcus, M.A., Manceau, A., Kersten, M., 2004. Mn, Fe, Zn, and As speciation in a fastgrowing ferromanganese marine nodule. Geochim. Cosmochim. Acta 68, 3125-3136.

McKenzie, R.M., 1970. Reaction of cobalt with manganese dioxide minerals. Australian Journal of Soil Research 8, 97-106.

McLaren, R.G., Crawford, D.V., 1973. Studies on soil copper .II. Specific adsorption of copper by soils. Journal of Soil Science 24, 443-452.

Morgan, J.J., 2000. Manganese in natural waters and earth's crust: Its availability to organisms, in: Siegel, A., Siegel, H. (Eds.), Metal Ions in Biological Systems: Iron Transport and Storage in Microorganisms, Plants, and Animals. Marcel Dekker, New York, pp. 1-34.

Morgan, J.J., 2005. Kinetics of reaction between $\mathrm{O}_{2}$ and $\mathrm{Mn}$ (II) species in aqueous solutions. Geochim. Cosmochim. Acta 69, 35-48.

Morton, J.D., Semrau, J.D., Hayes, K.F., 2001. An X-ray absorption spectroscopy study of the structure and reversibility of copper adsorbed to montmorillonite clay. Geochim. Cosmochim. Acta 65, 2709-2722.

Nelson, Y.M., Lion, L.W., Ghiorse, W.C., Shuler, M.L., 1999. Production of biogenic Mn oxides by Leprothrix discophora SS-1 in a chemically defined growth medium and evaluation of their $\mathrm{Pb}$ adsorption characteristics. Appl. Environ. Microbiol. 65, 175-180. 
Newville, M., Carroll, S., O'Day, P., Waychunas, G., Ebert, M., 1999. A web-based library of XAFS data on model compounds. J. Synchrotron Radiat., 276-277.

Peacock, C.L., Sherman, D.M., 2004. Copper(II) sorption onto goethite, hematite and lepidocrocite: A surface complexation model based on ab initio molecular geometries and EXAFS spectroscopy. Geochim. Cosmochim. Acta 68, 2623-2637.

Peacock, C.L., Sherman, D.M., 2007a. Crystal-chemistry of Ni in marine ferromanganese crusts and nodules. Am. Mineral. 92, 1087-1092.

Peacock, C.L., Sherman, D.M., 2007b. Sorption of Ni by birnessite: Equilibrium controls on Ni in seawater. Chem. Geol. 238, 94-106.

Peña, J., 2009. Contaminant Metal Immobilization by Biogenic Manganese Oxide Nanoparticles: Implications for Natural Attenuation and Bioremediation, Department of Civil and Environmental Engineering. University of California, Berkeley, p. 304.

Peña, J., Kwon, K.D., Refson, K., Bargar, J.R., Sposito, G., 2010. Mechanisms of nickel sorption by a bacteriogenic birnessite. Geochim. Cosmochim. Acta 74, 3076-3089.

Ravel, B., Newville, M., 2005. ATHENA, ARTEMIS, HEPHAESTUS: data analysis for Xray absorption spectroscopy using IFEFFIT. J. Synchrotron Radiat. 12, 537-541.

Rhehr, J.J., Zabinsky, S.I., Albers, R.C., 1992. High-order multiple scattering calculations of X-ray-absorption fine structure. Phys. Rev. Lett. 69, 3397.

Rodda, D.P., Wells, J.D., Johnson, B.B., 1996. Anomalous adsorption of copper(II) on goethite. J. Colloid Interface Sci. 184, 564-569.

Santelli, C.M., Webb, S.M., Dohnalkova, A.C., Hansel, C.M., 2011. Diversity of Mn oxides produced by Mn(II)-oxidizing fungi. Geochim. Cosmochim. Acta 75, 2762-2776.

Schecher, W.D., McAvoy, D.C., 2001. MINEQL+, in: Schecher, W.D., McAvoy, D.C. (Eds.), 4.5 ed. Environmental Research Software, Hallowell, ME.

Shannon, R.D., 1976. Revised effective ionic-radii and systematic studies of interatomic distances in halides and chalcogenides. Acta Crystallographica Section A 32, 751-767.

Sherman, D.M., Peacock, C.L., 2010. Surface complexation of $\mathrm{Cu}$ on birnessite (delta$\mathrm{MnO}_{2}$ ): Controls on $\mathrm{Cu}$ in the deep ocean. Geochim. Cosmochim. Acta 74, 6721-6730.

Shimizu, K., Maeshima, H., Yoshida, H., Satsuma, A., Hattori, T., 2001. Ligand field effect on the chemical shift in XANES spectra of $\mathrm{Cu}$ (II) compounds. Physical Chemistry Chemical Physics 3, 862-866.

Sposito, G., 2008. The Chemistry of Soils, 2nd ed. Oxford University Press, New York. 
Strawn, D.G., Palmer, N.E., Furnare, L.J., Goodell, C., Amonette, J.E., Kukkadapu, R.K., 2004. Copper sorption mechanisms on smectites. Clays and Clay Minerals 52, 321-333.

Takahashi, Y., Manceau, A., Geoffroy, N., Marcus, M.A., Usui, A., 2007. Chemical and structural control of the partitioning of $\mathrm{Co}, \mathrm{Ce}$, and $\mathrm{Pb}$ in marine ferromanganese oxides. Geochim. Cosmochim. Acta 71, 984-1008.

Tan, H., Zhang, G.X., Heaney, P.J., Webb, S.M., Burgos, W.D., 2010. Characterization of manganese oxide precipitates from Appalachian coal mine drainage treatment systems. Appl. Geochem. 25, 389-399.

Tebo, B.M., Bargar, J.R., Clement, B.G., Dick, G.J., Murray, K.J., Parker, D., Verity, R., Webb, S.M., 2004. Biogenic manganese oxides: Properties and mechanisms of formation. Annu. Rev. Earth Planet. Sci. 32, 287-328.

Toner, B., Manceau, A., Webb, S.M., Sposito, G., 2006. Zinc sorption to biogenic hexagonalbirnessite particles within a hydrated bacterial biofilm. Geochim. Cosmochim. Acta 70, 2743.

Traina, S.J., Doner, H.E., 1985a. Copper manganese(II) exchange on a chemically reduced birnessite. Soil Sci. Soc. Am. J. 49, 307-313.

Traina, S.J., Doner, H.E., 1985b. Heavy-metal induced releases of manganese(II) from a hydrous manganese-dioxide. Soil Sci. Soc. Am. J. 49, 317-321.

Vetter, K.J., Jaeger, N., 1966. Potentialausbildung an der Mangandioxid-Elektrode als oxidelektrode mit nichtstöchiometrischem oxid. Electrochim. Acta, 401-419.

Villalobos, M., Bargar, J., Sposito, G., 2005. Mechanisms of $\mathrm{Pb}(\mathrm{II})$ sorption on a biogenic manganese oxide. Environ. Sci. Technol. 39, 569-576.

Villalobos, M., Lanson, B., Manceau, A., Toner, B., Sposito, G., 2006. Structural model for the biogenic Mn oxide produced by Pseudomonas putida. Am. Mineral. 91, 489-502.

Villalobos, M., Toner, B., Bargar, J., Sposito, G., 2003. Characterization of the manganese oxide produced by Pseudomonas putida strain MnB1. Geochim. Cosmochim. Acta 67, 26492662.

Wang, Y., Feng, X., Villalobos, M., Tan, W., Liu, F., 2012. Sorption behavior of heavy metals on birnessite: Relationship with its Mn average oxidation state and implications for types of sorption sites. Chem. Geol. 292, 25-34.

Webb, S.M., 2004. SIXPack: a Graphical User Interface for XAS Analysis Using IFEFFIT. Phys. Scr. T115, 1011-1014. 
Webb, S.M., Tebo, B.M., Bargar, J.R., 2005. Structural characterization of biogenic Mn oxides produced in seawater by the marine Bacillus sp. strain SG-1. Am. Mineral. 90, 13421357.

Xia, K., Bleam, W., Helmke, P.A., 1997. Studies of the nature of binding sites of first row transition elements bound to aquatic and soil humic substances using X-ray absorption spectroscopy. Geochim. Cosmochim. Acta 61, 2223-2235. 
A.

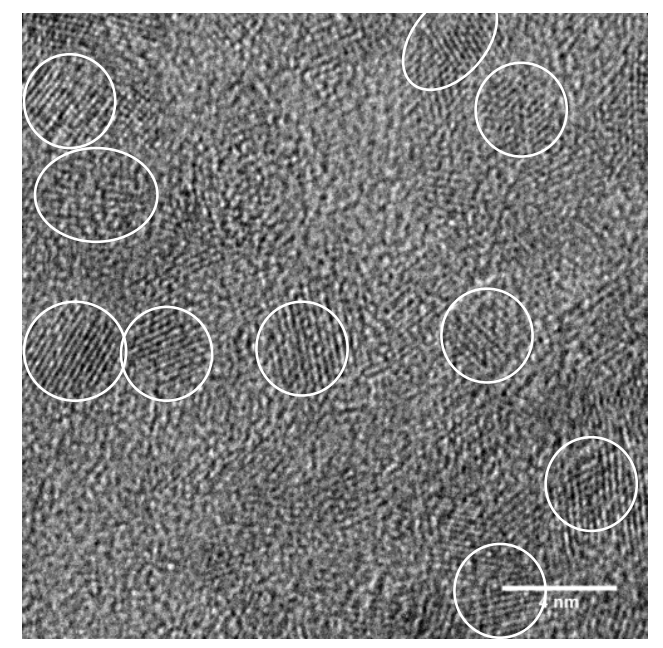

B.

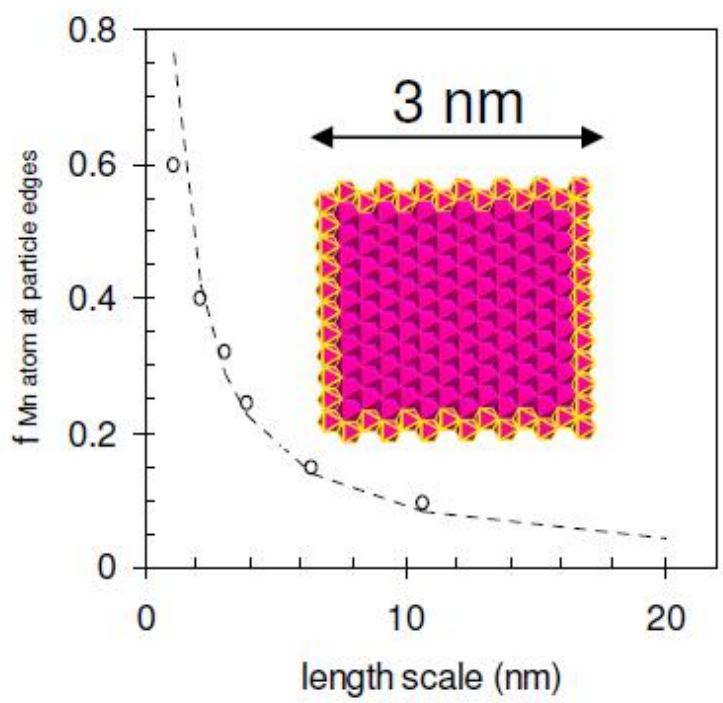

Figure 1. A) HR-TEM image of $\delta-\mathrm{MnO}_{2}$ particles acquired near Scherzer defocus using a Philips CM300 microscope; average particle size is $3.2 \pm 0.6 \mathrm{~nm}$ (10 particles, each measured along $x$ and $y$ directions); approximate particle boundaries are circled in white. B) Fraction $(f)$ of Mn octahedra located at particle edges for square birnessite particles with varying particle size. The inset illustrates how $f$ was determined for a 3 nm particle (Mn octahedra at particle edges / total number of Mn octahedra $=0.3$ ). 


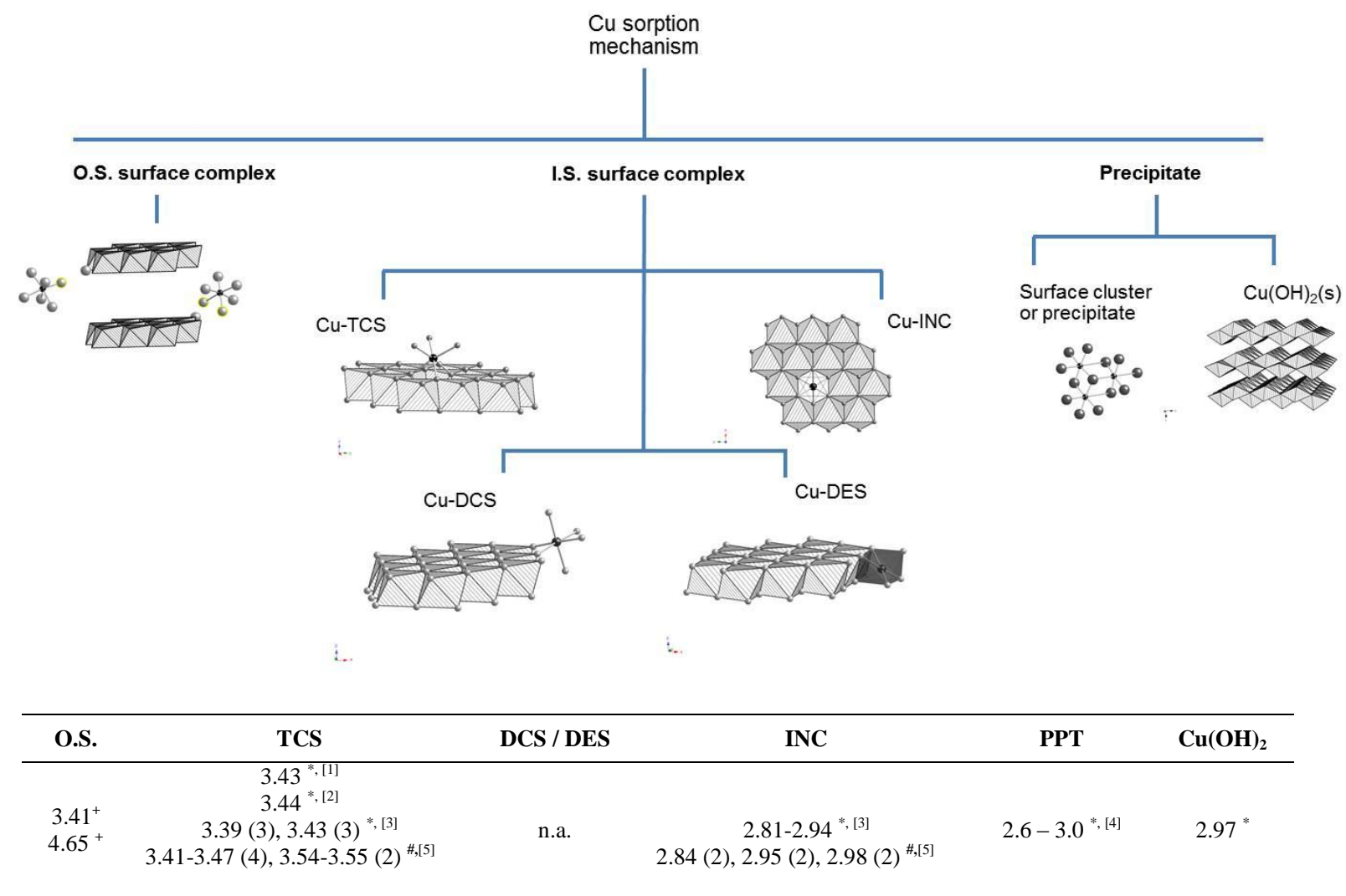

Figure 2. Schematic of $\mathrm{Cu}$ sorbate configurations and corresponding interatomic distances for second-shell neighbors: $\mathrm{Cu}-\mathrm{O}$ (outer-sphere surface complex, O.S.), $\mathrm{Cu}$ Mn (inner-sphere surface complex, I.S.), or $\mathrm{Cu}-\mathrm{Cu}$ (precipitate). The abbreviations TCS, DCS, DES, and INC indicate different $\mathrm{Cu}$ sorbate configurations: triple-corner sharing, double-corner sharing, double-edge sharing, and incorporated, respectively. Interatomic distances are based on experimental values (*) from Manceau et al. (2002) ${ }^{1}$, Peña $(2009)^{2}$, Sherman and Peacock $(2010)^{3}$, and Cheah et al. (2000) ${ }^{4}$; geometric considerations (+); or theoretical values from DFT geometry optimizations (\#) from Kwon et al. $(2013)^{4}$. The number in parentheses refers to the fitted coordination number. 


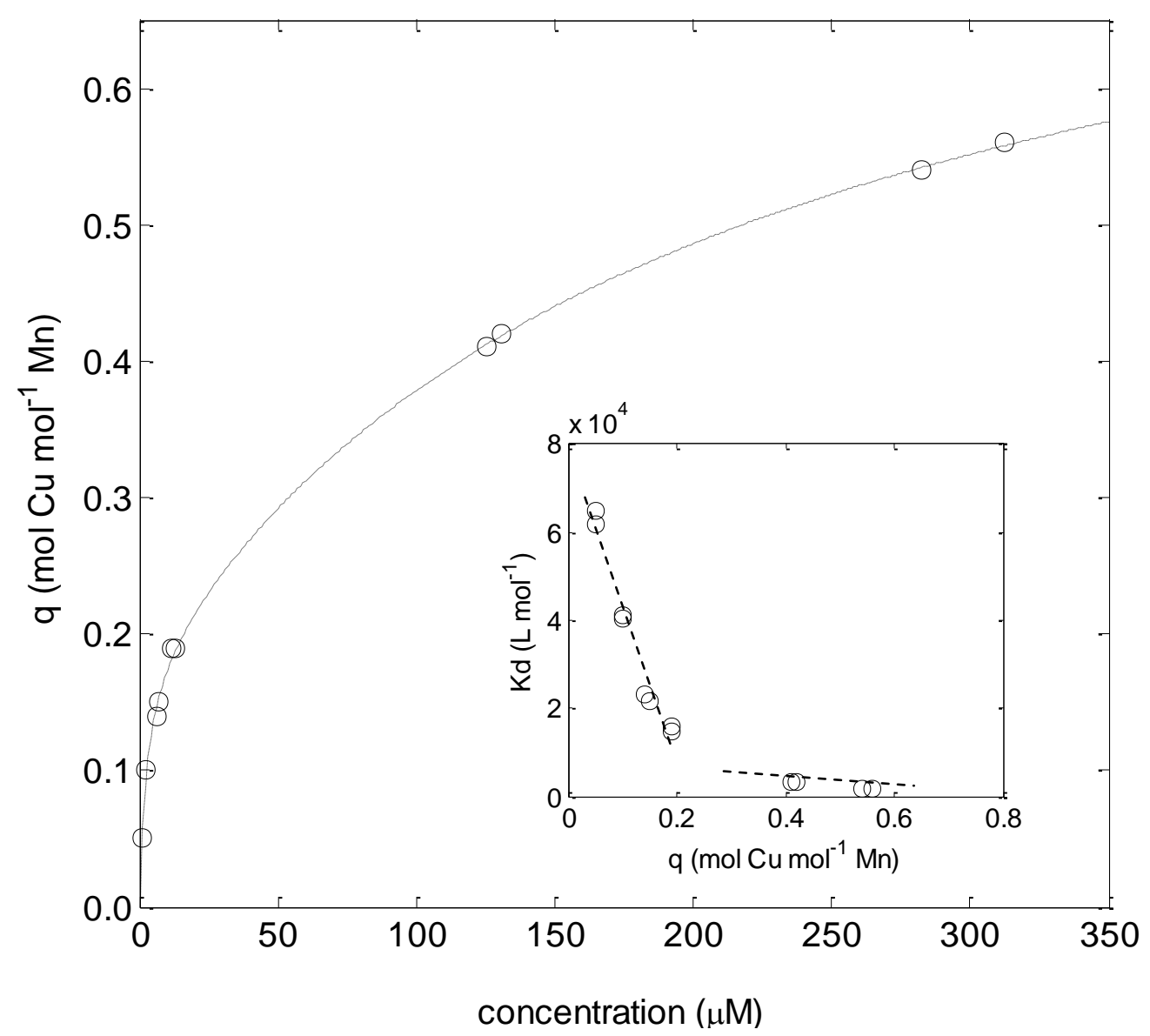

Figure 3. Sorption of $\mathrm{Cu}$ by $\delta-\mathrm{MnO}_{2}$ at $\mathrm{pH}$ 6. Surface excess $(q)$ expressed as a molar ratio of adsorbed $\mathrm{Cu}$ to $\mathrm{Mn}$ oxide adsorbent $\left(\mathrm{mol} \mathrm{Cu} \mathrm{mol}^{-1} \mathrm{Mn}\right)$ is plotted against aqueous $\mathrm{Cu}$ concentration $(\mu \mathrm{M})$. The inset shows a plot of the distribution coefficient, $K_{d}$ against surface excess, $q$. Dashed lines are intended as guides to the eye. 


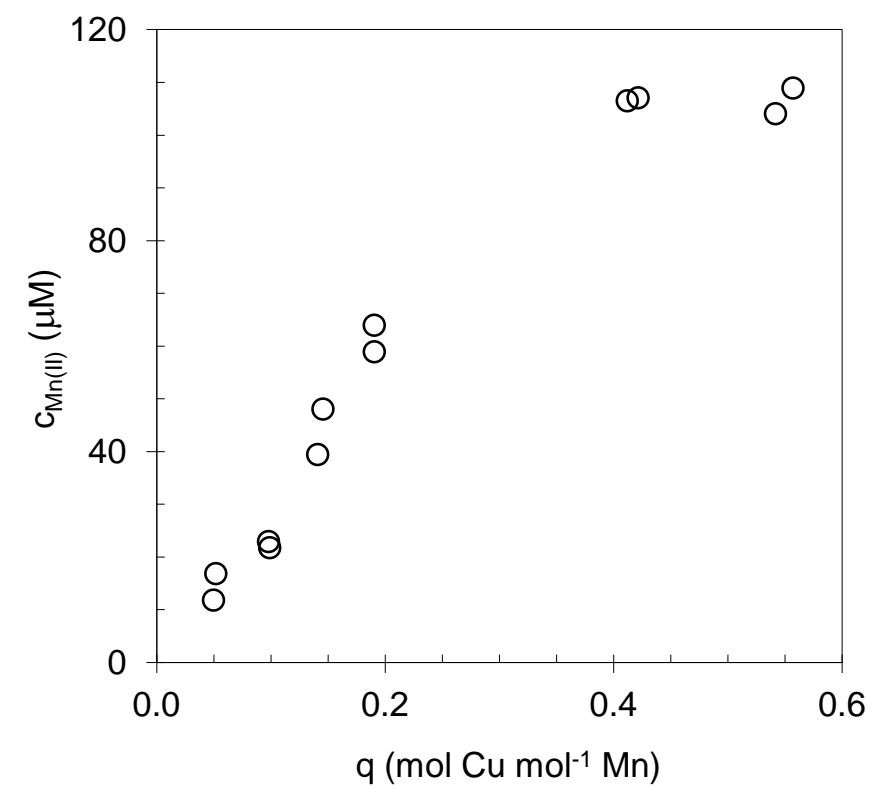

Figure 4. Concentration of aqueous $\mathrm{Mn}(\mathrm{II})(\mu \mathrm{M})$ released upon $\mathrm{Cu}$ sorption plotted against surface excess (mol $\mathrm{Cu} \mathrm{mol}^{-1} \mathrm{Mn}$ ); $\mathrm{Mn}$ (II) concentrations were adjusted by the fraction of $\mathrm{Mn}(\mathrm{II})$ released in $\mathrm{Cu}-\mathrm{free} \delta-\mathrm{MnO}_{2}$ suspensions. 
a.

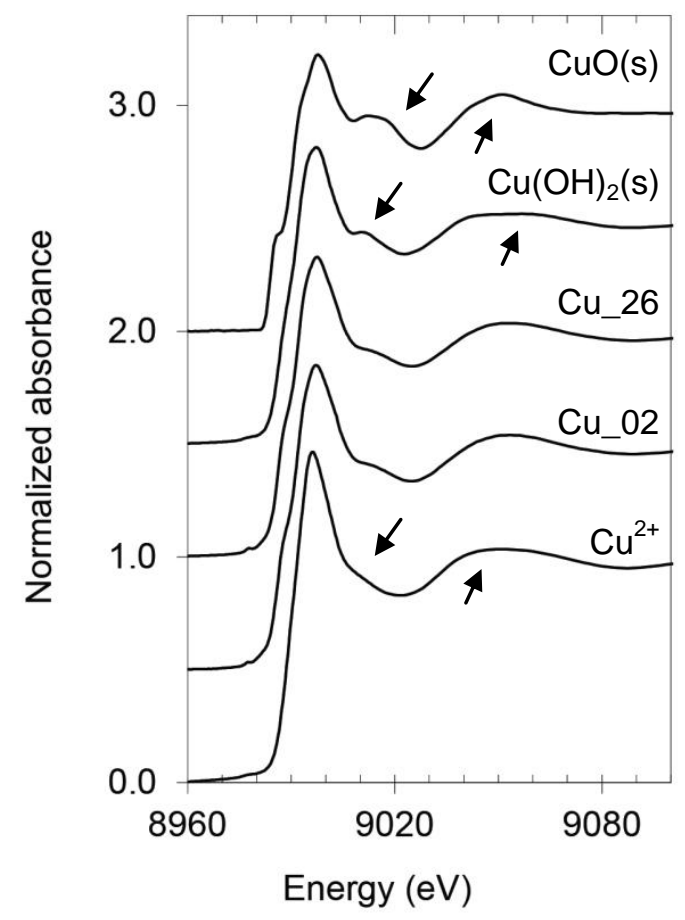

b.

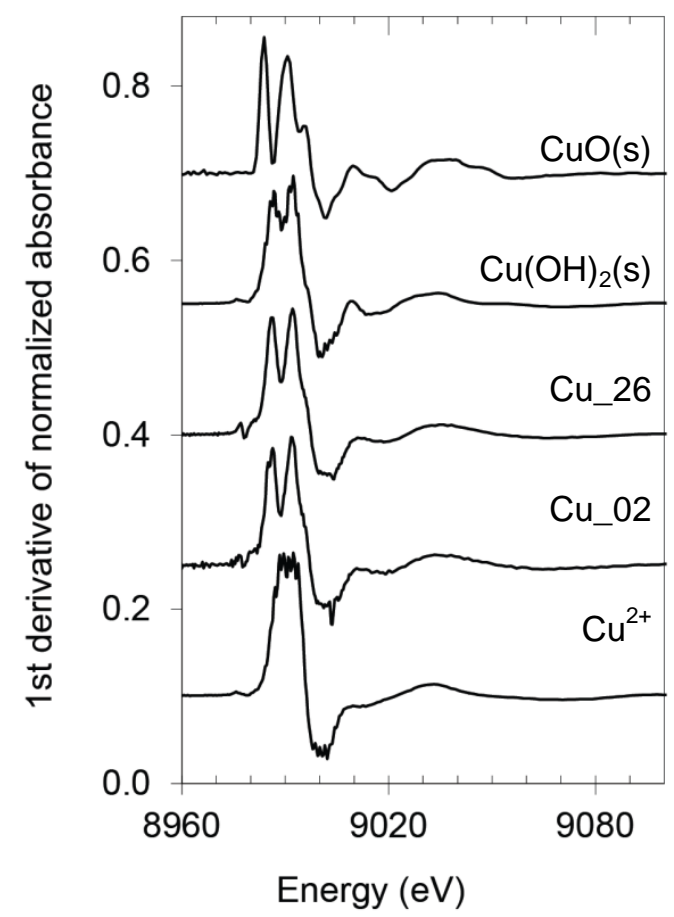

Figure 5. Normalized Cu K-edge XANES spectra (a) and their first derivatives (b) for reference materials and $\mathrm{Cu}-\delta-\mathrm{MnO}_{2}$ samples. Arrowheads point to features present in the XANES spectra of Cu solids that are absent in those from the experimental samples. 

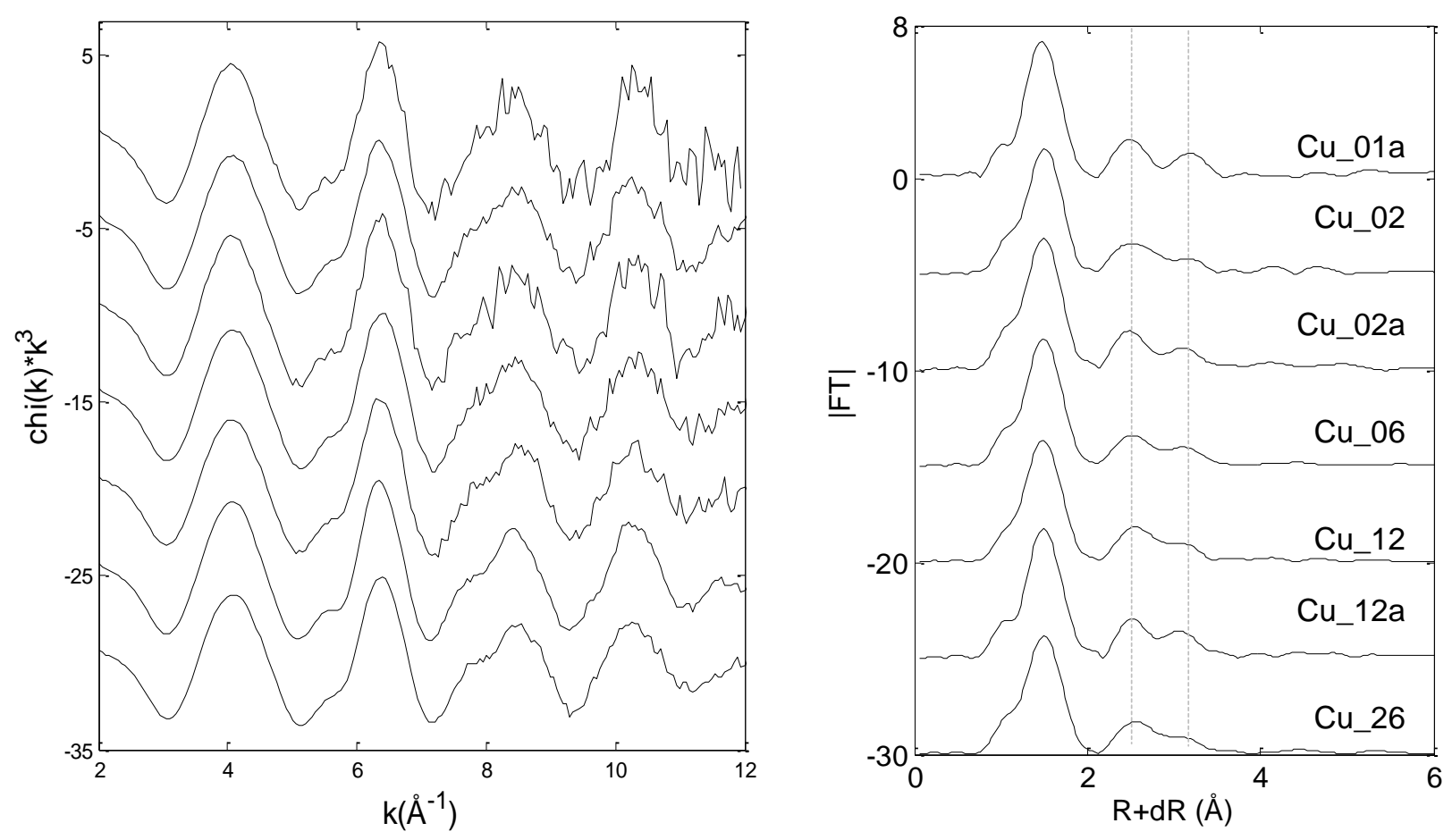

Figure 6. Cu K-edge EXAFS spectra and corresponding Fourier transforms for samples listed in Table 2: Cu_01a (top); Cu_02; Cu_02a; Cu_06; Cu_12; Cu_12a; Cu_26 (bottom). 


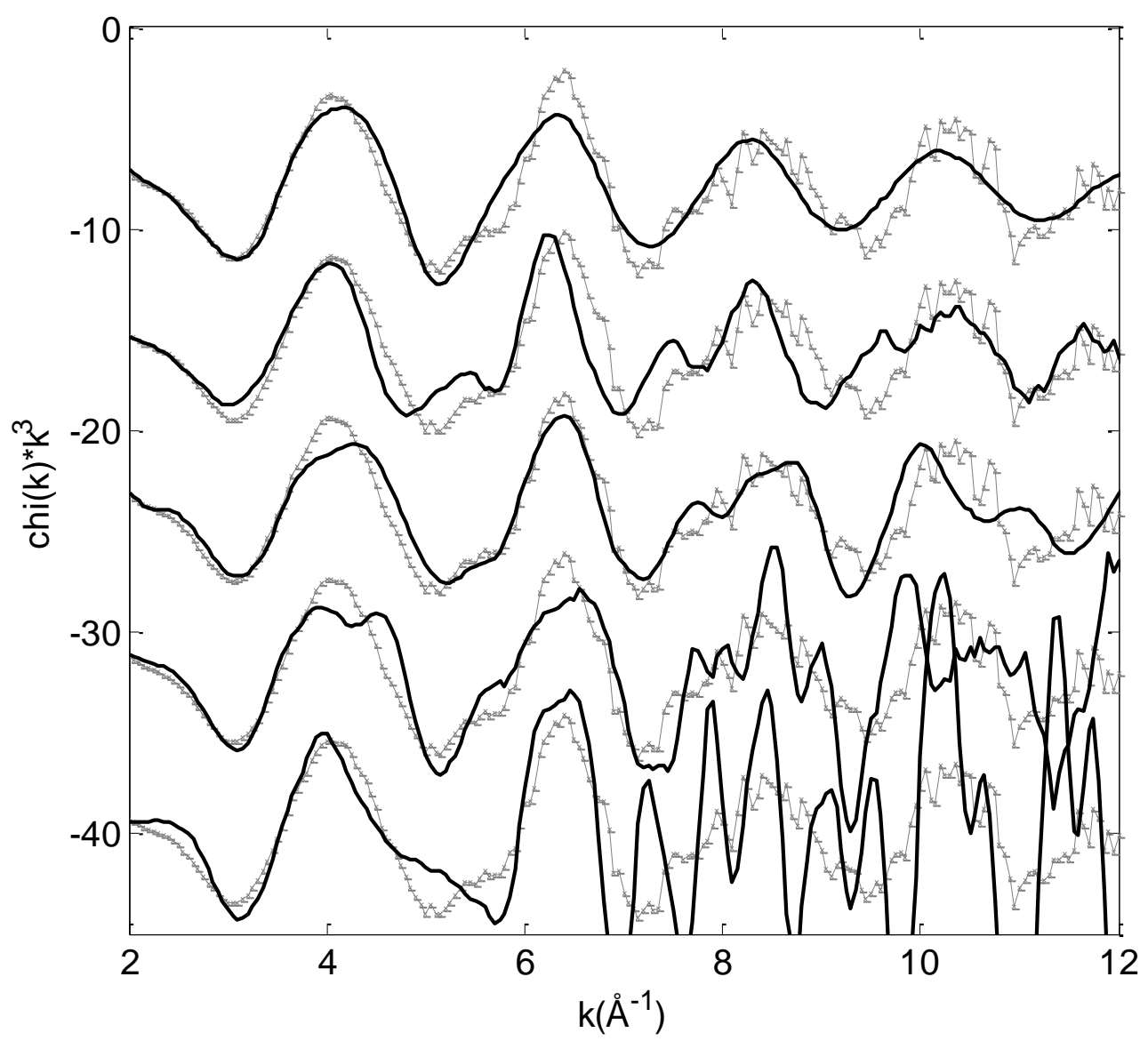

Figure 7a. Cu K-edge EXAFS spectrum from sample Cu_02a (grey line) overlain with various reference materials (black lines): $\mathrm{Cu}^{2+}$ (top), $\mathrm{Cu}$-biogenic $\mathrm{MnO}, \mathrm{Cu}(\mathrm{OH})_{2}$, $\mathrm{CuCO}_{3} \mathrm{OH}$, and $\mathrm{CuO}$ (bottom). 


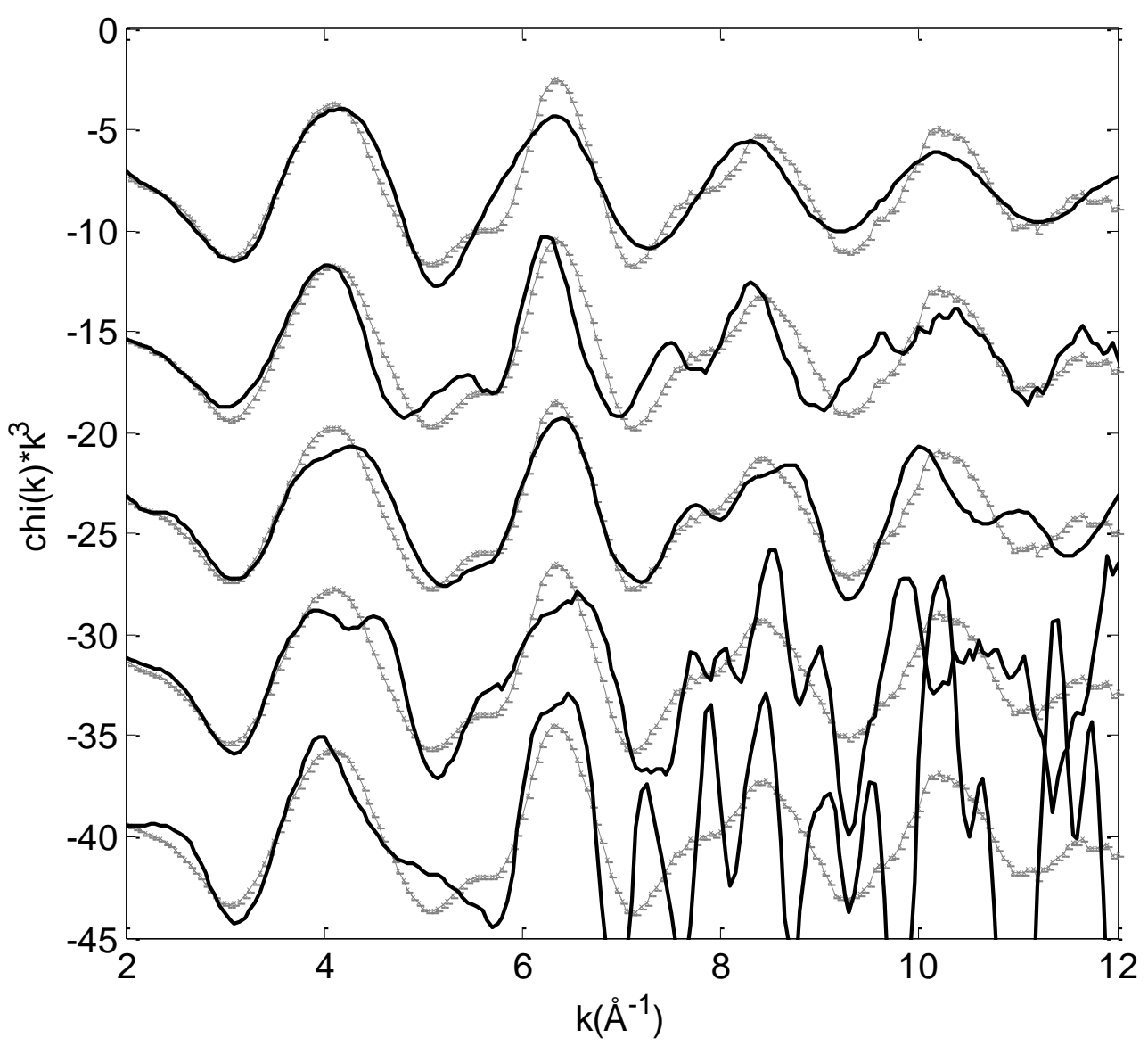

Figure 7b. Cu K-edge EXAFS spectrum from sample Cu_12a (grey line) overlain with the EXAFS spectra from various reference materials (black lines): $\mathrm{Cu}^{2+}($ top), $\mathrm{Cu}$ biogenic $\mathrm{MnO} 2, \mathrm{Cu}(\mathrm{OH})_{2}, \mathrm{CuCO}_{3} \mathrm{OH}$, and $\mathrm{CuO}$ (bottom). 


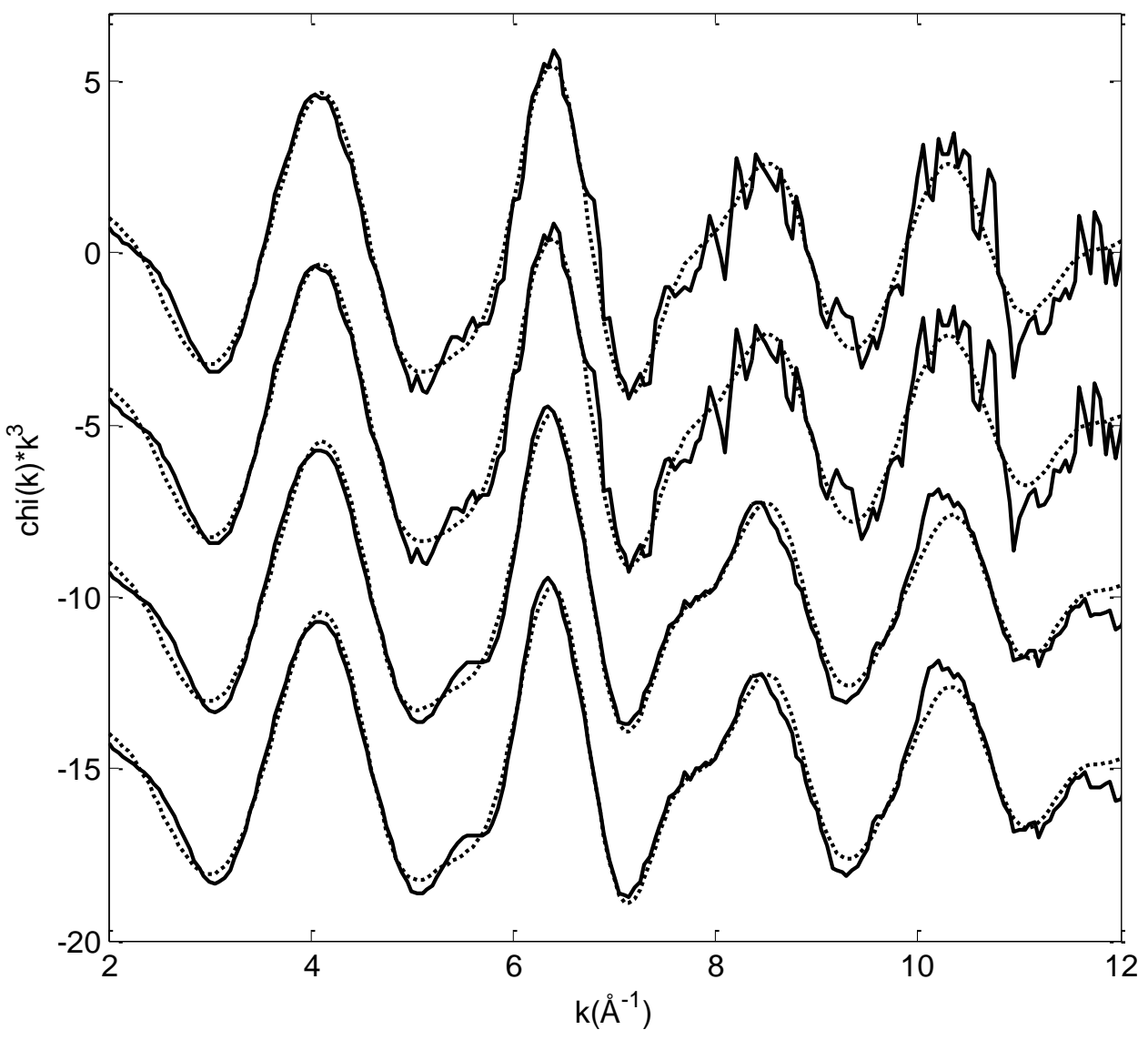

Figure 8. Cu K-edge EXAFS spectra (solid lines) from sample Cu_2a (solid line; top two spectra) and Cu_12a (solid line, bottom two spectra) plotted with best-fit curves (dashed line) for structural models described in the text (see Table 2). 
a.

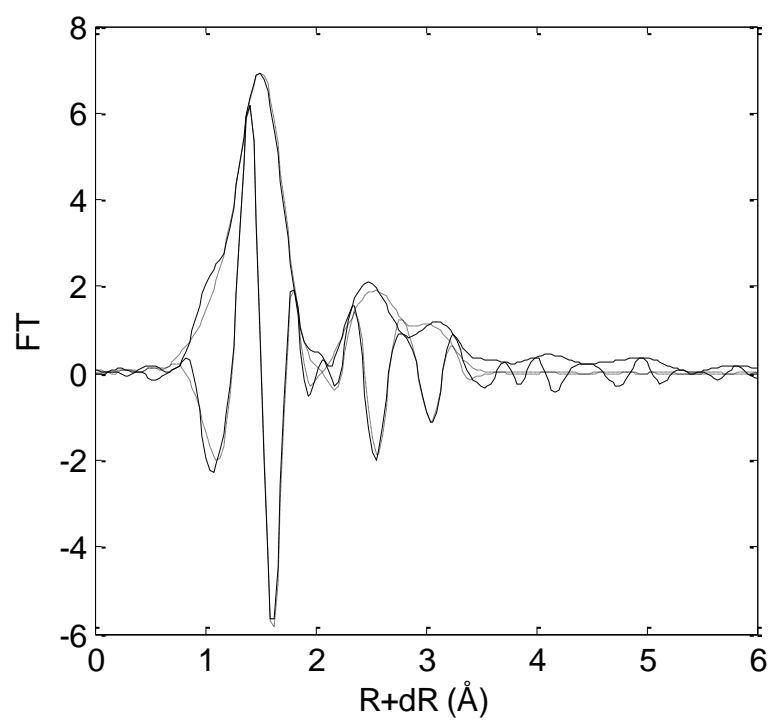

c.

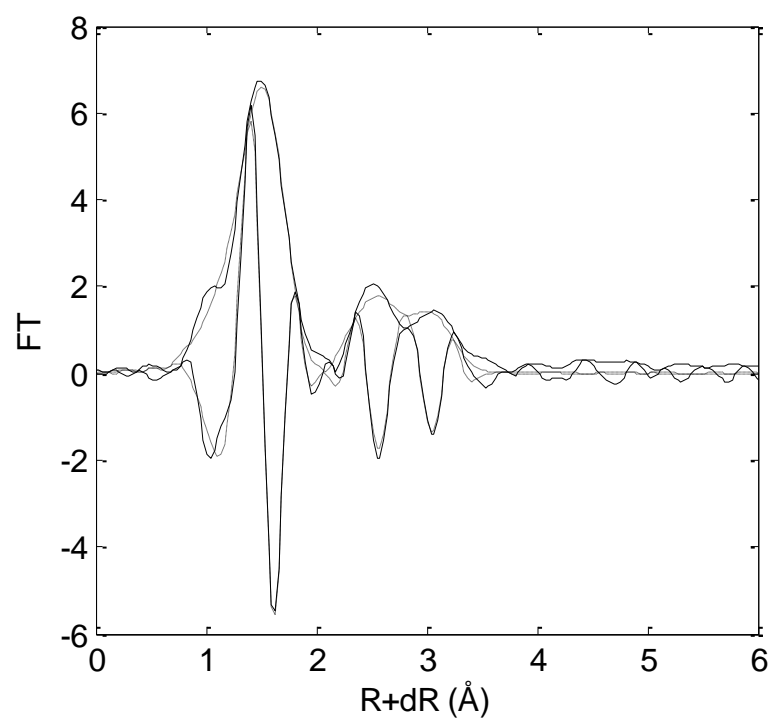

b.

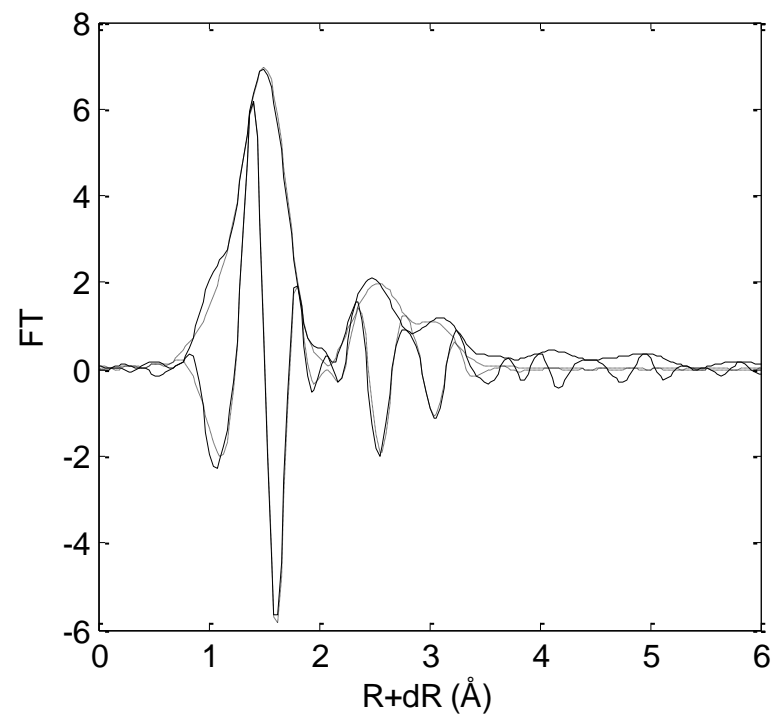

d.

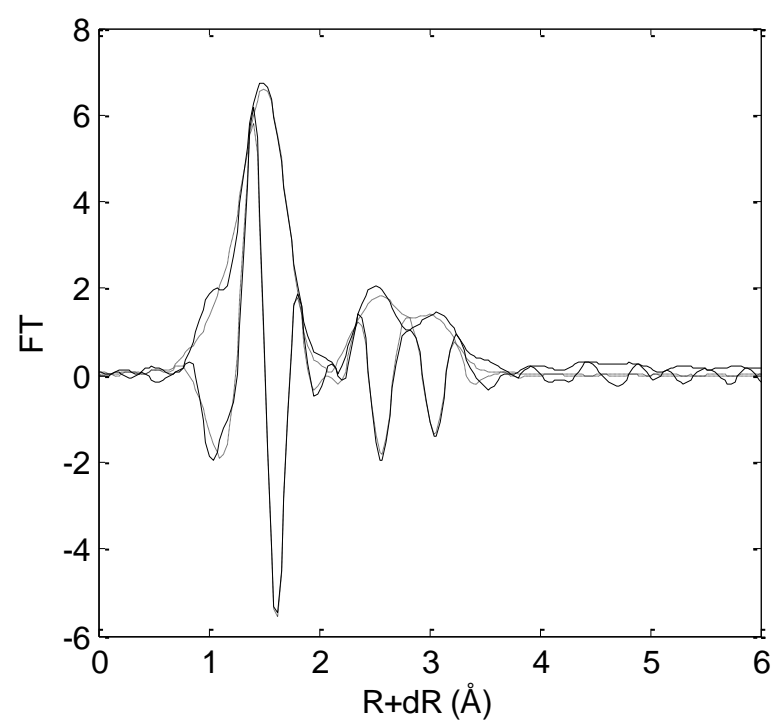

Figure 9. Fourier transforms (magnitude and imaginary part) of the $\mathrm{Cu} \mathrm{K}$-edge EXAFS spectra from samples $\mathrm{Cu}$ _2a (a, b) and $\mathrm{Cu} \_$12a (c, d) (solid lines) plotted with best-fit curves (dashed lines) for the structural models described in Table 2: $\mathrm{Cu}-\mathrm{O}, \mathrm{Cu}-\mathrm{Cu}$ and $\mathrm{Cu}-\mathrm{Mn}(\mathrm{a}, \mathrm{c})$ and $\mathrm{Cu}-\mathrm{O}, \mathrm{Cu}-\mathrm{Mn}$ and $\mathrm{Cu}-\mathrm{Mn}(\mathrm{b}, \mathrm{d})$. 
Table 1. Samples investigated by EXAFS spectroscopy. Sample ID indicates the Cu:Mn molar ratio $\times 100$. The difference between the initial and final aqueous $\mathrm{Cu}$ concentrations $\left(\Delta c_{\mathrm{Cu}}\right)$ and final aqueous $M n$ concentration are reported in the third and fourth columns. The $\mathrm{Cu}$ surface excess is expressed as a $\mathrm{Cu}$ :Mn molar ratio in the fifth column $(q)$. Finally, saturation index values $(\Omega)$ are reported for $\mathrm{CuO}(\mathrm{s})$ and $\mathrm{Cu}(\mathrm{OH})_{2} \mathrm{CO}_{3}(\mathrm{~s})$ in the sixth and seventh columns, respectively.

\begin{tabular}{|c|c|c|c|c|c|c|}
\hline $\begin{array}{l}\text { Sample } \\
\text { ID }\end{array}$ & $\mathrm{pH}_{\mathrm{eq}}$ & $\begin{array}{l}\Delta c_{\mathrm{Cu}} \\
(\boldsymbol{\mu M})\end{array}$ & $\begin{array}{c}c_{\mathrm{Mn}}^{1} \\
(\mu \mathrm{M})\end{array}$ & $\begin{array}{c}q^{2} \\
\left(\mathrm{~mol} \mathrm{Cu} \mathrm{mol}^{-1} \mathrm{Mn}\right)\end{array}$ & $\mathbf{\Omega}_{C u O(s)}$ & $\mathbf{\Omega}_{\mathrm{cu}(\mathrm{OH}) 2 \mathrm{CO}(\mathrm{s})}$ \\
\hline $\mathrm{Cu} \_01 \mathrm{a}$ & 5.99 & 25 & 26 & 0.011 & 0.36 & 0.01 \\
\hline $\mathrm{Cu} \_02 \mathrm{a}$ & 5.99 & 50 & 26 & 0.023 & 0.70 & 0.05 \\
\hline $\mathrm{Cu}_{-} 12 \mathrm{a}$ & 5.95 & 257 & 31 & 0.112 & 3.00 & 0.98 \\
\hline $\mathrm{Cu} \_02$ & 6.13 & 37 & 8 & 0.019 & 0.99 & 0.11 \\
\hline $\mathrm{Cu} \_06$ & 6.12 & 108 & 8 & 0.055 & 2.76 & 0.83 \\
\hline $\mathrm{Cu}_{-} 12$ & 6.08 & 208 & 17 & 0.115 & 4.44 & 2.14 \\
\hline $\mathrm{Cu} \_26$ & 6.02 & 444 & 51 & 0.258 & 7.34 & 5.83 \\
\hline
\end{tabular}

${ }^{1}$ Concentrations of 28 and $9 \mu \mathrm{M}$ Mn were measured in the absence of $\mathrm{Cu}$ at $\mathrm{pH} 6.03$ and 6.15 , respectively.

${ }^{2}$ The concentration of $\mathrm{Mn}$ in the solid phase was $2.29 \pm 0.05 \mathrm{mM}(\mathrm{pH} 6.0)$ and $1.85 \pm 0.08$ (pH 6.1). 
Table 2. Representative fit parameters obtained from shell-by-shell fits to the EXAFS spectra presented in Figure 6. EXAFS-derived fitting uncertainties are reported in parenthesis.

\begin{tabular}{|c|c|c|c|c|c|c|c|c|c|c|}
\hline & \multicolumn{6}{|c|}{3 path fit: $\mathrm{Cu}-\mathrm{O}, \mathrm{Cu}-\mathrm{Cu}$, and $\mathrm{Cu}-\mathrm{Mn}$} & \multicolumn{4}{|c|}{3 path fit: $\mathrm{Cu}-\mathrm{O}, \mathrm{Cu}-\mathrm{Mn}$, and $\mathrm{Cu}-\mathrm{Mn}$} \\
\hline & & $\boldsymbol{R}(\AA)$ & $\sigma^{2}\left(\AA^{2}\right)$ & $C N$ & $E 0(\mathrm{eV})$ & & $\boldsymbol{R}(\AA)$ & $\sigma^{2}\left(\AA^{2}\right)$ & $C N$ & $E 0(\mathrm{eV})$ \\
\hline \multirow{3}{*}{$\begin{array}{c}\text { Global } \\
\text { parameters }\end{array}$} & $\mathrm{Cu}-\mathrm{O}$ & $1.94(0.002)$ & $0.005(0.0003)$ & \multirow{3}{*}{ Varied } & & $\mathrm{Cu}-\mathrm{O}$ & $1.94(0.002)$ & $0.005(0.0003)$ & \multirow{3}{*}{ varied } & \multirow{24}{*}{$\begin{array}{l}-4.08 \\
(0.39)\end{array}$} \\
\hline & $\mathrm{Cu}-\mathrm{Cu}$ & $2.88(0.006)$ & $0.007(0.002)$ & & -4.22 & $\mathrm{Cu}-\mathrm{Mn}$ & $2.90(0.006)$ & $0.004(0.002)$ & & \\
\hline & $\mathrm{Cu}-\mathrm{Mn}$ & $3.39(0.007)$ & $0.008(0.002)$ & & $(0.39)$ & $\mathrm{Cu}-\mathrm{Mn}$ & $3.39(0.007)$ & $0.008(0.002)$ & & \\
\hline \multirow{4}{*}{$\mathrm{Cu} \_01 \mathrm{a}$} & & & $\mathrm{Cu}-\mathrm{O}$ & $3.98(0.41)$ & & & & $\mathrm{Cu}-\mathrm{O}$ & $3.95(0.39)$ & \\
\hline & & & $\mathrm{Cu}-\mathrm{Cu}$ & $0.80(0.53)$ & & & & $\mathrm{Cu}-\mathrm{Mn}$ & $0.60(0.36)$ & \\
\hline & & & $\mathrm{Cu}-\mathrm{Mn}$ & $1.17(0.77)$ & & & & $\mathrm{Cu}-\mathrm{Mn}$ & $1.14(0.79)$ & \\
\hline & & & $\mathrm{Cu}-\mathrm{O}$ & $3.78(0.21)$ & & & & $\mathrm{Cu}-\mathrm{O}$ & $3.74(0.20)$ & \\
\hline \multirow[t]{3}{*}{$\mathrm{Cu} \_02$} & & & $\mathrm{Cu}-\mathrm{Cu}$ & $0.83(0.31)$ & & & & $\mathrm{Cu}-\mathrm{Mn}$ & $0.54(0.20)$ & \\
\hline & & & $\mathrm{Cu}-\mathrm{Mn}$ & $0.90(0.40)$ & & & & $\mathrm{Cu}-\mathrm{Mn}$ & $0.90(0.41)$ & \\
\hline & & & $\mathrm{Cu}-\mathrm{O}$ & $4.00(0.41)$ & & & & $\mathrm{Cu}-\mathrm{O}$ & $3.98(0.39)$ & \\
\hline \multirow[t]{3}{*}{$\mathrm{Cu} \_02 \mathrm{a}$} & & & $\mathrm{Cu}-\mathrm{Cu}$ & $0.91(0.53)$ & & & & $\mathrm{Cu}-\mathrm{Mn}$ & $0.61(0.34)$ & \\
\hline & & & $\mathrm{Cu}-\mathrm{Mn}$ & $1.19(0.78)$ & & & & $\mathrm{Cu}-\mathrm{Mn}$ & $1.17(0.79)$ & \\
\hline & & & $\mathrm{Cu}-\mathrm{O}$ & $3.80(0.27)$ & & & & $\mathrm{Cu}-\mathrm{O}$ & $3.78(0.25)$ & \\
\hline \multirow[t]{3}{*}{$\mathrm{Cu} \_06$} & & & $\mathrm{Cu}-\mathrm{Cu}$ & $0.77(0.37)$ & & & & $\mathrm{Cu}-\mathrm{Mn}$ & $0.50(0.23)$ & \\
\hline & & & $\mathrm{Cu}-\mathrm{Mn}$ & $0.98(0.51)$ & & & & $\mathrm{Cu}-\mathrm{Mn}$ & $0.99(0.53)$ & \\
\hline & & & $\mathrm{Cu}-\mathrm{O}$ & $3.67(0.24)$ & & & & $\mathrm{Cu}-\mathrm{O}$ & $3.64(0.23)$ & \\
\hline \multirow[t]{3}{*}{$\mathrm{Cu}_{-} 12$} & & & $\mathrm{Cu}-\mathrm{Cu}$ & $0.85(0.35)$ & & & & $\mathrm{Cu}-\mathrm{Mn}$ & $0.56(0.22)$ & \\
\hline & & & $\mathrm{Cu}-\mathrm{Mn}$ & $1.05(0.48)$ & & & & $\mathrm{Cu}-\mathrm{Mn}$ & $1.05(0.50)$ & \\
\hline & & & $\mathrm{Cu}-\mathrm{O}$ & $3.78(0.13)$ & & & & $\mathrm{Cu}-\mathrm{O}$ & $3.75(0.12)$ & \\
\hline \multirow[t]{3}{*}{$\mathrm{Cu} \_12 \mathrm{a}$} & & & $\mathrm{Cu}-\mathrm{Cu}$ & $0.78(0.24)$ & & & & $\mathrm{Cu}-\mathrm{Mn}$ & $0.52(0.14)$ & \\
\hline & & & $\mathrm{Cu}-\mathrm{Mn}$ & $1.47(0.38)$ & & & & $\mathrm{Cu}-\mathrm{Mn}$ & $1.46(0.39)$ & \\
\hline & & & $\mathrm{Cu}-\mathrm{O}$ & $3.58(0.14)$ & & & & $\mathrm{Cu}-\mathrm{O}$ & $3.56(0.13)$ & \\
\hline \multirow[t]{2}{*}{$\mathrm{Cu} \_26$} & & & $\mathrm{Cu}-\mathrm{Cu}$ & $0.81(0.25)$ & & & & $\mathrm{Cu}-\mathrm{Mn}$ & $0.53(0.14)$ & \\
\hline & & & $\mathrm{Cu}-\mathrm{Mn}$ & $1.05(0.48)$ & & & & $\mathrm{Cu}-\mathrm{Mn}$ & $0.94(0.30)$ & \\
\hline
\end{tabular}

Note: $R=$ interatomic distance; $\sigma^{2}=$ Debye-Waller factor; $C N=$ coordination number; $E O=$ energy shift; the R-factor is a goodness of fit parameter. All Cu K-edge EXAFS spectra were fit simultaneously with $R, \sigma^{2}$, and $E O$ varied globally and the $C N$ varied for each spectrum, over a $k$-range 2.5 to $12 \AA^{-1}$ and with $k$-weights of 2 and 3 $\AA^{-1}$. Both fits had 108 independent points and 28 variables. The R-factor was 0.003 . 


\section{Annex}

Table A.1. Optimized fit parameters for Mn K-edge EXAFS spectra of birnessite sample collected in transmission mode. The dry, unreacted mineral sample was diluted in powdered sugar.

\begin{tabular}{lcccccc}
\hline Sample ID & $\mathbf{M n}-\mathbf{X}$ & $\mathbf{C N}$ & $\mathbf{R}(\AA)$ & $\sigma^{2}\left(\AA^{2}\right)$ & $\Delta \mathbf{E}_{\mathbf{0}}(\mathrm{eV})$ & R-factor \\
\hline$\delta-\mathrm{MnO}_{2}$ & $\mathrm{O}$ & $5.45 \pm 0.93$ & $1.91 \pm 0.008$ & $0.005 \pm 0.001$ & $7.39 \pm 1.73$ & 0.010 \\
& $\mathrm{Mn}$ & $4.39 \pm 0.90$ & $2.87 \pm 0.010$ & $0.006 \pm 0.001$ & & \\
\hline
\end{tabular}

Note: The backscattering atom $(\mathrm{X})$ used in the fit is listed in the second column. Fits were done in $R$-space from $1-3.0 \AA$ and using a k-range of $3-11.7 \AA^{-1}$. Fit parameters [interatomic distance $R(\AA)$, coordination number $C N$, and mean-square displacement of bond length $\left.\sigma^{2}\left(\AA^{2}\right)\right]$ are reported together with their IFEFFIT-derived uncertainties.

Table A.2. Data for $\mathrm{Cu}$ sorption on $\delta-\mathrm{MnO}_{2}$

\begin{tabular}{|c|c|c|c|c|c|c|c|}
\hline pH & $\begin{array}{c}\mathbf{c}_{\text {Mn_TOT }} \\
(\mu \mathrm{M}) \\
\end{array}$ & $\begin{array}{c}\mathbf{c}_{\text {Cu_toT }} \\
(\mu \mathrm{M})\end{array}$ & $\begin{array}{c}\mathbf{c}_{\text {Mn_FIN }} \\
(\mu \mathrm{M})\end{array}$ & $\begin{array}{c}\mathbf{c}_{\text {Cu_FIN }} \\
(\mu \mathrm{M})\end{array}$ & $\begin{array}{c}\mathbf{q} \\
\left(\mathrm{mol} \mathrm{mol}^{-1}\right) \\
\end{array}$ & $\begin{array}{c}\mathbf{c}_{\text {Mn_FIN }} / \\
\mathbf{c}_{\text {MnTOT }} \\
(-)\end{array}$ & $\begin{array}{c}\mathrm{Kd} \\
\left(\mathrm{L} \mathrm{mol}^{-1}\right)\end{array}$ \\
\hline 5.78 & 1975.72 & n.a. & 35.42 & n.a. & n.a. & 0.02 & n.a. \\
\hline 6.03 & 2343.28 & n.a. & 28.36 & n.a. & n.a. & 0.01 & n.a. \\
\hline 5.98 & 1343.84 & 68.79 & 33.32 & 0.81 & 0.05 & 0.02 & 63890 \\
\hline 5.99 & 1736.89 & 85.63 & 33.11 & 0.77 & 0.05 & 0.02 & 64621 \\
\hline 5.97 & 1713.61 & 166.01 & 43.93 & 2.42 & 0.10 & 0.03 & 40554 \\
\hline 5.97 & 1805.80 & 176.96 & 43.90 & 2.48 & 0.10 & 0.02 & 39944 \\
\hline 5.93 & 1947.85 & 280.13 & 71.93 & 6.97 & 0.15 & 0.04 & 20899 \\
\hline 5.96 & 2039.65 & 284.57 & 64.43 & 6.07 & 0.14 & 0.03 & 23234 \\
\hline 5.89 & 1958.09 & 369.21 & 87.95 & 12.89 & 0.19 & 0.04 & 14779 \\
\hline 5.89 & 1990.58 & 375.32 & 83.31 & 11.87 & 0.19 & 0.04 & 16050 \\
\hline 5.86 & 2022.32 & 899.61 & 143.43 & 125.52 & 0.41 & 0.07 & 3282 \\
\hline 5.86 & 1977.62 & 903.87 & 143.18 & 130.66 & 0.42 & 0.07 & 3226 \\
\hline 5.80 & 2454.52 & 1531.71 & 148.87 & 282.65 & 0.54 & 0.06 & 1917 \\
\hline 5.77 & 2281.67 & 1499.75 & 150.58 & 312.61 & 0.56 & 0.07 & 1782 \\
\hline
\end{tabular}

Note: The $\mathrm{pH}$ averaged over all samples was $5.90 \pm 0.07$; the solid concentration averaged over all samples was $1.94 \pm 0.28 \mathrm{mM} \mathrm{Mn}\left(0.17 \pm 0.02 \mathrm{~g} \mathrm{~L}^{-1}\right.$ assuming $\mathrm{M}_{\mathrm{r}}=87 \mathrm{~g} \mathrm{MnO}_{2} \mathrm{~L}^{-1}$ and excluding mass contribution from exchangeable $\mathrm{Na}^{+}$or adsorbed water). 

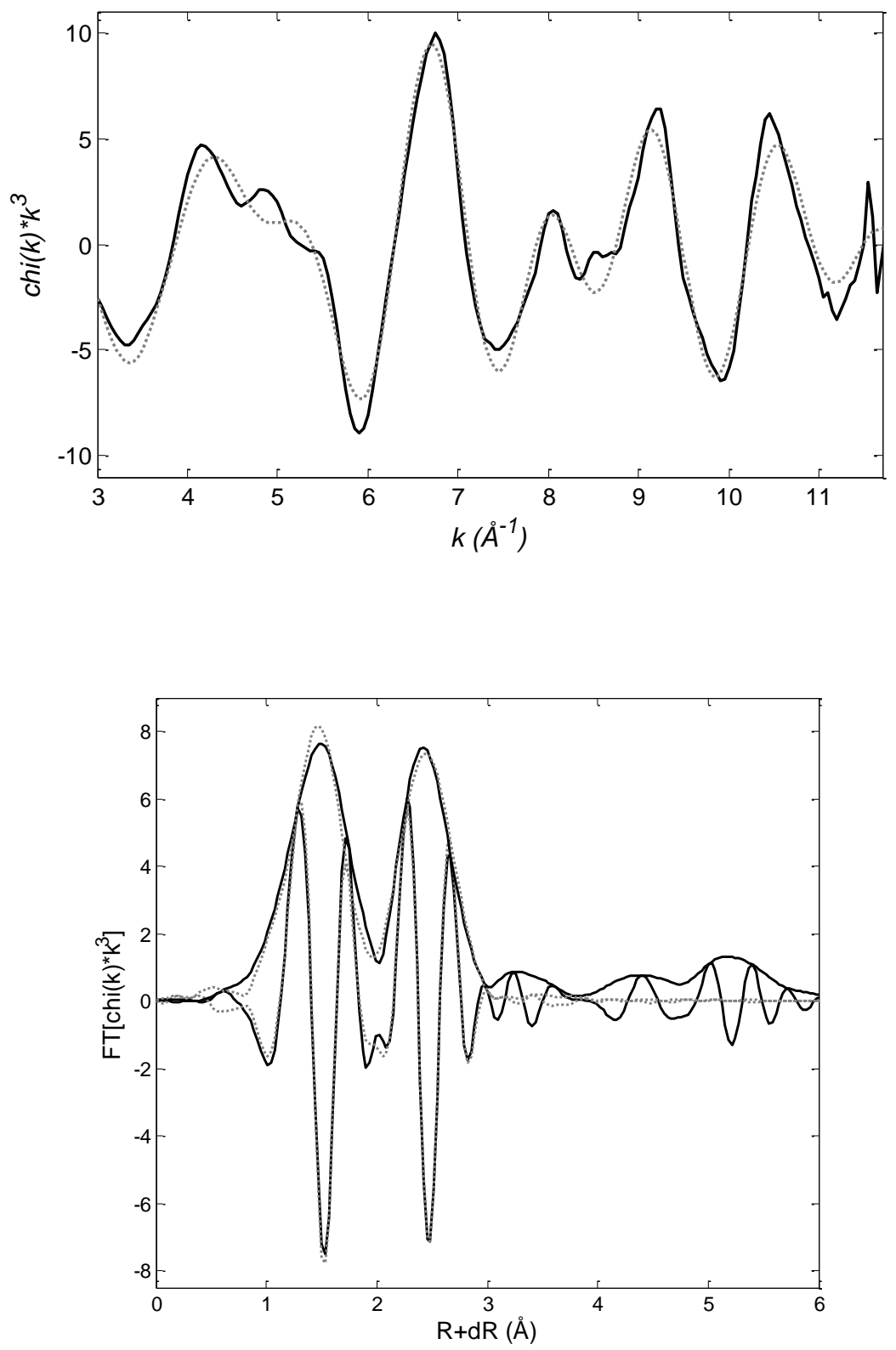

Figure A.1. Mn K-edge EXAFS spectrum (a) and Fourier transform (b) from $\delta-\mathrm{MnO}_{2}$ powder (solid line) plotted with best-fit curve for Mn-O and Mn-Mn near neighbors (dashed line). Fit parameters are summarized in Table A.1. 


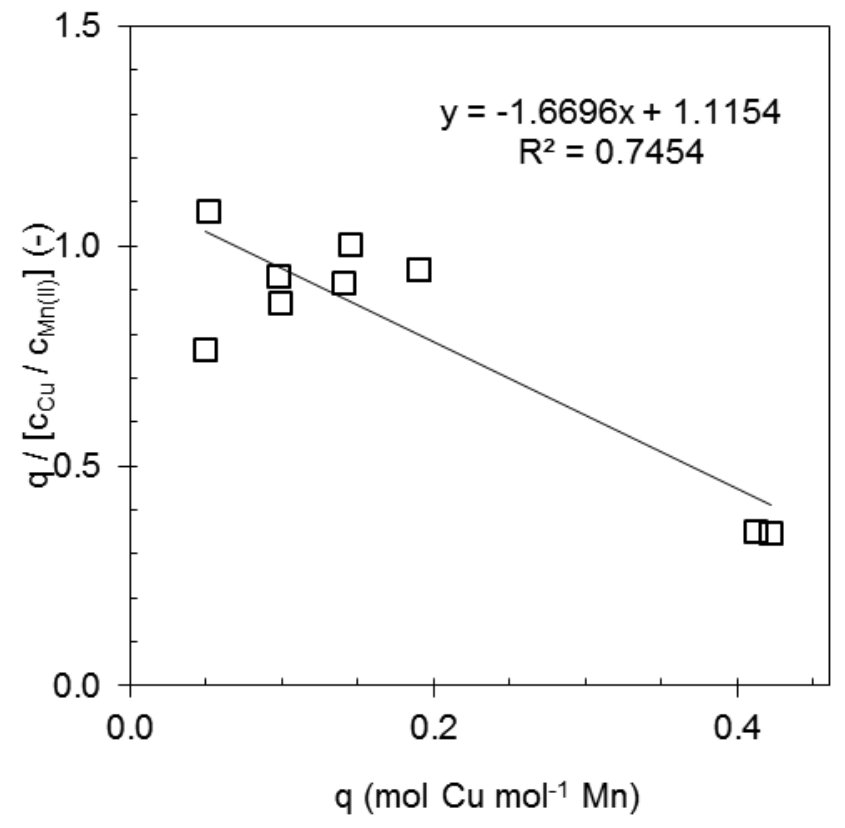

Figure A.2. Plot of $q$ / $\left(c_{-} C u / c_{-M n(I I)}\right)$ versus q at pH 6. Solid line shows the least-squares fit for $q$-values $<0.4 \mathrm{~mol} \mathrm{Cu} \mathrm{mol}^{-1} \mathrm{Mn}$. 